\begin{tabular}{|c|c|}
\hline - $199720 ;$ ENGINEERING DATA TRANSMITTAL & 1. EDT 615793 \\
\hline
\end{tabular}

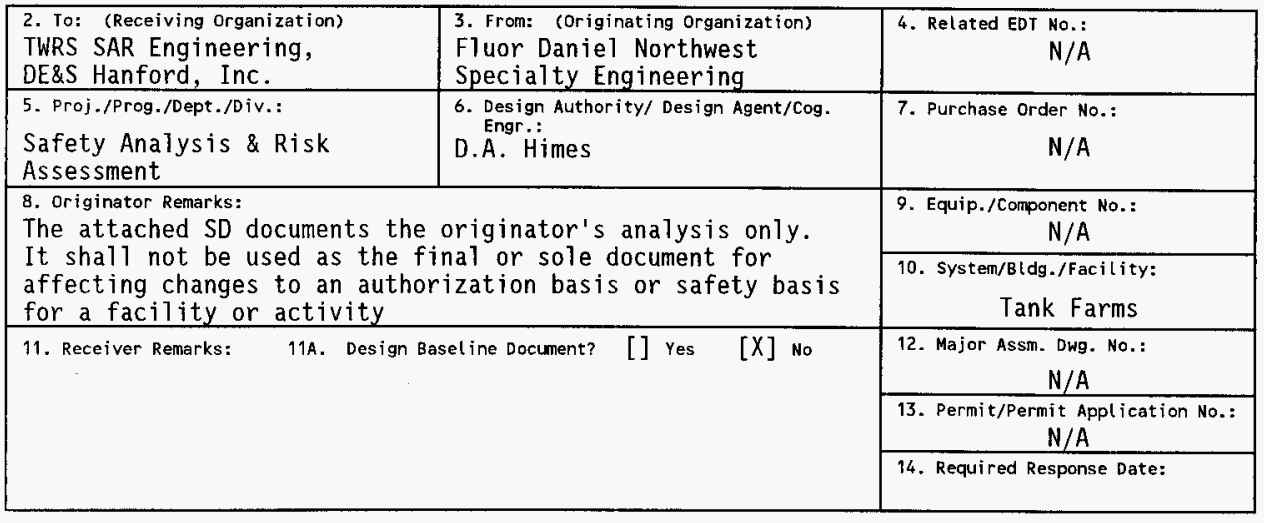

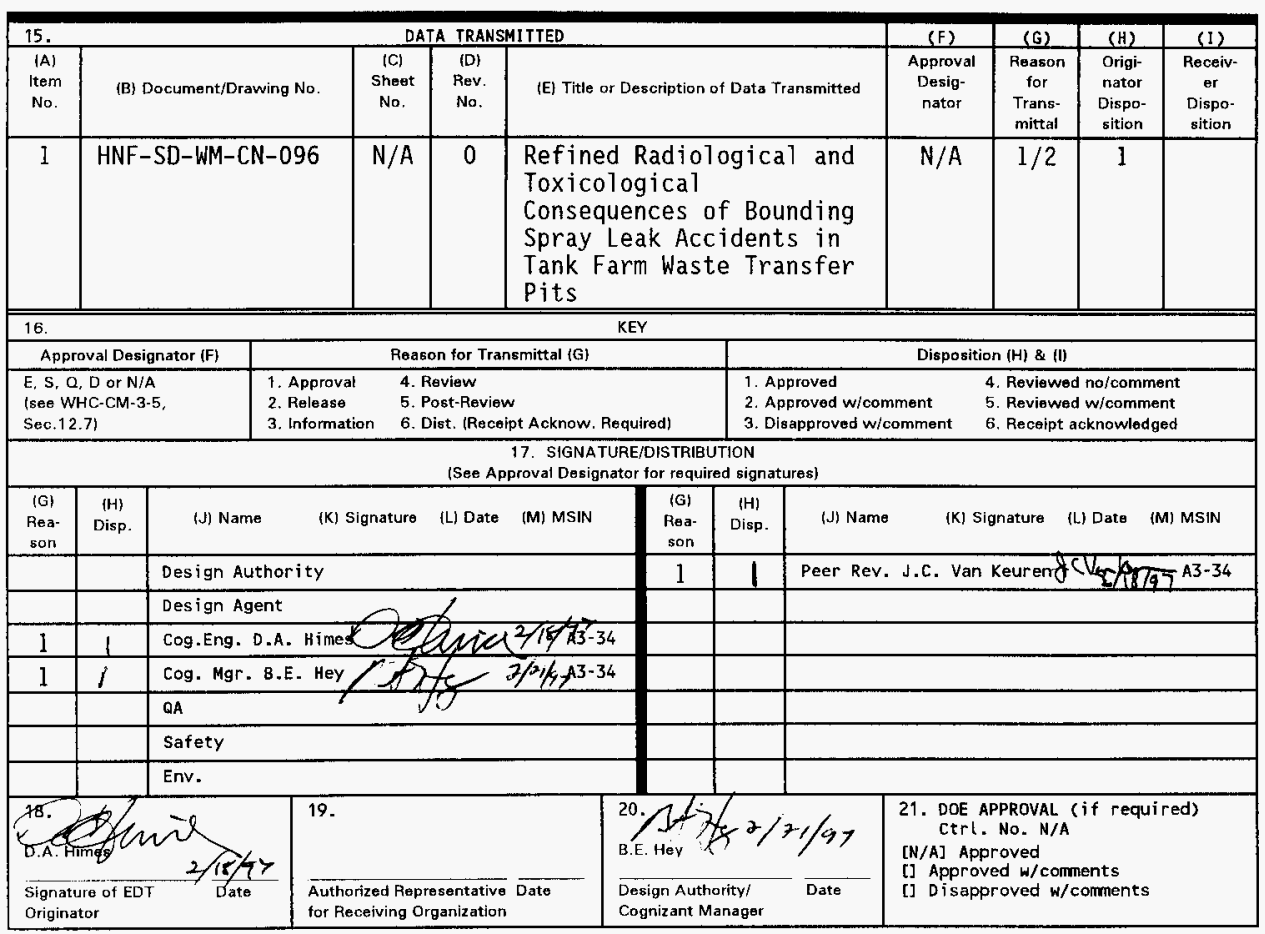




\title{
Refined Radiological and Toxicological Consequences of Bounding Spray Leak Accidents in Tank Farm Waste Transfer Pits
}

\section{D.A. Himes}

Fluor Daniel Northwest Inc., Richland, WA 99352

U.S. Department of Energy Contract DE-AC06-96RL13200

\author{
EDT/ECN: $615793 \quad$ UC: 510 \\ Org Code: $403 \quad$ Charge Code: E52874 \\ B\&R Code: EW31220071 Tota1 Pages: 37
}

Key Words: spray, aerosol, TWRS, jumper, pit

Abstract: This document contains revised analyses of bounding spray leaks in tank farm waste transfer pits incorporating more realistic assumptions and accident models than previous analyses. In addition, several refinements in the analysis models suggested during the reviews of previous analyses were investigated. Refinements which proved to have a significant effect on the results were included. Mitigated spray leaks involving both DST and AWF wastes were brought below risk guidelines for accident frequencies in the anticipated range.

TRADEMARK DISCLAIMER. Reference herein to any specific commercial product, process, or service by
trade name, trademark, manufacturer, or otherwise, does not necessarily constitute or imply its
endorsement, recomnendation, or favoring by the United States Government or any agency thereof or endorsement, recommendation, or favi
its contractors or subcontractors.

Printed in the United States of America. To obtain copies of this document, contact: WHC/BCS Document Control Services, P.O. Box 1970, Mailstop H6-08, Richland WA 99352, Phone (509) 372-2420; Fax (509) 376-4989.
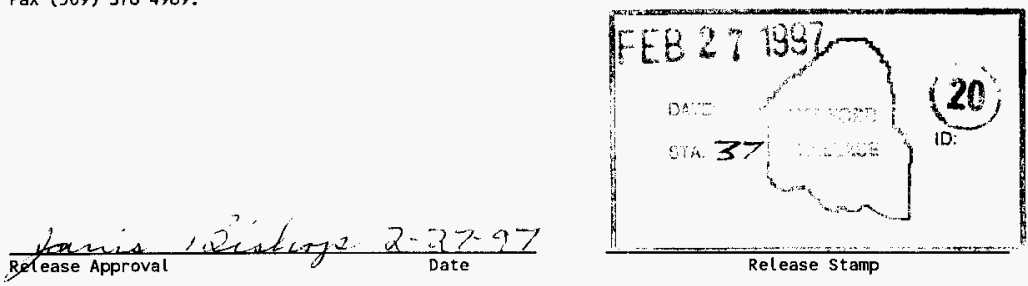

\section{Approved for Public Release}




\title{
REFINED RADIOLOGICAL AND TOXICOLOGICAL CONSEQUENCES OF BOUNDING SPRAY LEAK ACCIDENTS IN TANK FARM WASTE TRANSFER PITS
}

\author{
D.A. Himes \\ $2 / 12 / 97$
}

Radiological and toxicological consequences of spray leak accidents in Hanford liquid waste tank farm pits were previously estimated and reported in WHC-SDWM-CN-048 Rev 1, Calculation Notes in Support of TWRS FSAR Spray Leak Accident Analysis (Hall 1996a) in support of the Tank Waste Remediation System (TWRS) Final Safety Analys is Report (FSAR). The present document contains revised analyses incorporating more realistic assumptions and accident models than the previous document. In addition, several refinements in the analysis models suggested during the review of WHC-SD-CN-048 were investigated. Refinements which proved to have a significant effect on the results were included in the present analysis.

\section{Accident Scenarios:}

Three bounding accident scenarios have been chosen to represent the range of spray leaks which could occur in the below-grade valve and jumper pits in the tank farm:

$\Rightarrow \quad$ An unmitigated spray leak from an open valve pit. The spray is assumed to be directed up and out of the pit with an undetermined amount of slurry falling to the ground outside. The size of the pit is therefore immaterial and the leak detector is assumed not to function. A bounding slurry mix consisting of 33\% AWF solids and $67 \%$ AWF 1iquids is assumed for this release. (The effects of varying solids content was investigated.) The leak is assumed to continue unabated for 24 hours with the offsite receptor being exposed to the entire plume. The onsite receptor is exposed to the first 12 hours of the release. This

corresponds to one maximum 12-hour shift. The effect of self-evacuation of the onsite receptor after 1 hour was also investigated. Although a transfer would not ordinarily be made through an uncovered valve pit, this event could occur due to a transfer being misrouted.

$\Rightarrow \quad$ A Double-Shell Tank (DST) slurry spray leak in a valve pit with the cover on (mitigated case 1). In this case, the inside volume of the pit directly effects the amount of release so the largest pit which could be used for a DST waste transfer is assumed. Consequences were calculated both with and without the benefit of a pit leak detector. In addition the effect of varying the leak size was investigated in order to determine the worst case. (A high volume leak increases the release rate, but trips the leak detector or submerges the leak sooner.) The release occurs at a relatively low rate by air displacement through small openings in the pit covers, and so is assumed to be undetected by the onsite receptor $100 \mathrm{~m}$ downwind. Both the onsite and offsite receptors are therefore assumed to be exposed for the duration of the 
release. This type of leak would be expected to nearly always occur due to a misaligned jumper connection, but in rare cases could instead be due to a crack in a pipe or fitting (most likely at a weld).

$\Rightarrow \quad$ An Aging Waste Facility (AWF) slurry spray leak in a valve pit with the cover on (mitigated case 2). This case is essentially identical to mitigated case 1 except for the slurry source and a smaller maximum pit size for AWF transfers.

\section{Atmospheric Transport:}

Receptor locations and atmospheric dispersion factors $\left(X / Q^{\prime}\right)$ were developed and are reported in WHC-SD-WM-SARR-016 Rev 2, Tank Waste Compositions and Atmospheric Dispersion Coefficients for Use in Safety Analys is Consequence Assessments (Van Keuren 1996a). The steady-state X/Q's reported (defined to be the air concentration at the receptor per unit release rate, or, for steady-state conditions, time integrated air concentration at the receptor location per unit total release) are for general use and therefore do not include plume depletion due to fallout of particulates. For this analysis the $X / Q$ 's were specialized by being corrected for plume depletion due to fallout based on data from an actual release from a waste transfer pit.

On January 11, 1985 a release of fission products occurred in the $C$ Tank Farm from the 241-C-151 Diversion Box (Stupka 1986) apparently due to an accidenta1 pressurization of a line leading to an open nozzle in the box. This forced a quantity of air with entrained waste through gaps in the diversion box cover blocks. Based on air sampler data and ground contamination the release was primarily $\mathrm{Sr}-90(1.4 \mathrm{Ci})$ with some $\mathrm{Cs}-137(0.02$ Ci). Due to a snow cover on the ground and favorable meteorology, this incident presented a highly unusual opportunity to make accurate measurements of ground contamination which, when combined with air sampler data, permitted determination of particulate deposition velocity under field conditions without the masking interference of background contamination in the soil. Two calculations of total release were made by using air sampler data and by using ground contamination data. Excellent agreement between the two determinations was obtained with the Chamberlain plume depletion model using a deposition velocity of $0.15 \mathrm{~cm} / \mathrm{s}$. This is very close to the recommended generic value of $0.1 \mathrm{~cm} / \mathrm{s}$ for deposition velocity of respirable particulates (Napier 1988). Note that resuspension of the deposited material would be a third order effect compared to exposure to the primary plume, and is negligible unless the receptor is assumed to reside downwind of the contamination for an extended period of time (i.e., years). Long term exposure to the resuspended material would be evaluated based on actual surveys as part of the recovery effort.

Using a deposition velocity of $0.15 \mathrm{~cm} / \mathrm{s}$, the GXQ code (Hey 1994) was used to calculate onsite and offsite $X / Q^{\prime}$ 's incorporating plume depletion by dry deposition using the Chamberlain model. Onsite $(100 \mathrm{~m})$ and offsite (site boundary) values of $X / Q^{\prime}$ were calculated for release (averaging) times of 1 hour (no plume meander), 2 hours (with plume meander), and annual average (sector averaged). For release durations intermediate between 2 hours and 1 year $(8760 \mathrm{~h})$, the standard logarithmic averaging formulation was used where the $X / Q^{\prime}$ over a release time of $x$ hours is given by: 


$$
\ln \left(\frac{\mathrm{x}}{Q^{\prime}}\right)_{x}=\left[\ln \left(\frac{\mathrm{x}}{Q^{\prime}}\right)_{1 y}-\ln \left(\frac{\mathrm{x}}{Q^{\prime}}\right)_{2 h}\right]\left[\frac{\ln (x)-\ln (2)}{\ln (8760)-\ln (2)}\right]+\ln \left(\frac{\mathrm{x}}{Q^{\prime}}\right)_{2 h}
$$

where it is assumed that the release rate is reasonably constant over the time $x$ hours. Other than the addition of plume depletion, this is consistent with the methodology used in WHC-SD-WM-SARR-016 (Van Keuren 1996a). The X/Q's with particle deposition used in this analysis are shown in Table 1 . The $X / Q$ 's without deposition effects taken from WHC-SD-WM-SARR-016 are also shown. The GXQ input/output files are included as Attachment 1.

Table 1: Atmospheric dispersion coefficients $(X / Q)$ with and without deposition effects

\begin{tabular}{|c|c|c|c|}
\hline \multirow[b]{2}{*}{ Receptor } & \multirow[b]{2}{*}{$\begin{array}{l}\text { Release } \\
\text { Duration }\end{array}$} & \multicolumn{2}{|c|}{$x / 0^{\prime}\left(\mathrm{s} / \mathrm{m}^{3}\right)$} \\
\hline & & $\begin{array}{c}\text { Without } \\
\text { Deposition }\end{array}$ & $\begin{array}{c}\text { With } \\
\text { Deposition }\end{array}$ \\
\hline Onsite & $\begin{array}{rl}\leq 1 & h r \\
2 & h r \\
6 & h r \\
8 & h r \\
12 & h r \\
1 & y\end{array}$ & $\begin{array}{l}3.41 \mathrm{E}-2 \\
1.13 \mathrm{E}-2 \\
7.31 \mathrm{E}-3 \\
6.52 \mathrm{E}-3 \\
5.55 \mathrm{E}-3 \\
4.03 \mathrm{E}-4\end{array}$ & $\begin{array}{l}2.91 \mathrm{E}-2 \\
1.05 \mathrm{E}-2 \\
6.79 \mathrm{E}-3 \\
6.05 \mathrm{E}-3 \\
5.15 \mathrm{E}-3 \\
3.75 \mathrm{E}-4\end{array}$ \\
\hline Offsite & 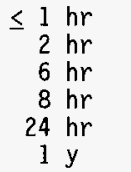 & $\begin{array}{l}2.83 \mathrm{E}-5 \\
2.12 \mathrm{E}-5 \\
1.08 \mathrm{E}-5 \\
9.06 \mathrm{E}-6 \\
4.62 \mathrm{E}-6 \\
1.24 \mathrm{E}-7\end{array}$ & $\begin{array}{l}1.61 \mathrm{E}-5 \\
1.20 \mathrm{E}-5 \\
6.26 \mathrm{E}-6 \\
5.28 \mathrm{E}-6 \\
2.75 \mathrm{E}-6 \\
8.35 \mathrm{E}-8\end{array}$ \\
\hline
\end{tabular}

Note that the $X / Q^{\prime}$ decreases rapidly as receptor distance increases, and also decreases with increasing averaging time (i.e., release duration at a constant rate). A given release will therefore produce more severe consequences if released over a shorter time than if released over a longer time.

\section{Spray Leak Model:}

The details of the spray leak were modelled using the SPRAY code (Hey and Leach 1994). For the unmitigated case, the maximum respirable release rate was produced by optimizing the crack width with respect to respirable fraction and assuming a crack length of 1 nominal pipe diameter, i.e. 2 inches. This is consistent with the leak assumed for this case in WHC-SD-WM-CN-048 and tends to maximize the amount of spray which could be directed up and out of the pit. Experience with the SPRAY code indicates that this type of leak has a relatively low total volume flow rate but maximizes the total respirable 
release rate. Larger leaks with higher volume flow rates are less efficient generators of respirable aerosol (i.e., lower respirable fraction), but because of the higher flow rate, the total respirable aerosol generation rate tends to have a relatively weak dependence on the size of the leak for leaks larger than the optimum size.

Consistent with WHC-SD-WM-CN-048, a density of $1.4 \mathrm{~g} / \mathrm{cm}^{3}$ was assumed for the spray slurry. This type of slurry is a non-Newtonian fluid which could have a viscosity of about $20 \mathrm{cPs}$ for shear rates encountered during normal flow in pipes during a transfer. For the high shear rates present in leakage through a narrow slit, however, a viscosity of $1 \mathrm{cPs}$ was assumed, again consistent with WHC-SD-WM-CN-048. Centrifugal pumps are not normally operated against a shutoff head for any length of time, so assuming a pump pressure at zero flowrate for the leak is unrealistic. Normal flow rates for typical transfers range from 50 to $100 \mathrm{gpm}$. From the applicable limiting pump curve for the cross-site transfer pump in Tank 102-SY given in Appendix B of WHC-SD-WM-CN048 , the pump head associated with a flow rate of $50 \mathrm{gpm}$ is $350 \mathrm{ft}$ for a liquid with a density of $1.7 \mathrm{~g} / \mathrm{cm}^{3}$, or a gage pressure at the pump of 260 psig. Allowing some pressure drop during transfer to the leak site for this conservative transfer rate, a pressure of 250 psig was assumed at the leak.

Care must be taken to correct for evaporation when defining the respirable size fraction of the spray release. A water droplet with an initial diameter $D_{i}$ and a volumetric dissolved or suspended solids fraction $E$ will, after evaporation of the water, form a solid particle with a final diameter $D_{f}$ approximately related to $D_{i}$ by $D_{i}=\left(D_{f}^{3} / E\right)^{1 / 3}$ (Hey and Leach 1994). The maximum respirable particle size is normally taken to be $10 \mu \mathrm{m}$. This size particle has a gravitational fall velocity (approximately $1 \mathrm{~cm} / \mathrm{s}$ ) about equal to the velocity associated with random vorticity in air. This is, therefore, also about the maximum size particulate which can be transported any distance from a ground level source under low wind speed conditions. For $D_{f}=10 \mu m$ and $E=0.33, D_{i}$ is $14.5 \mu \mathrm{m}$. The respirable fraction for the leak is therefore the fraction of aerosol particles with size less than or equal to $14.5 \mu \mathrm{m}$.

The width of the sealing surface in a jumper connector is approximately 0.16 inches $(0.406 \mathrm{~cm})$ which is essentially the same as the nominal wall thickness of 2 inch schedule 40 steel pipe (0.154 inches). If a crack did occur in a pipe or fitting, it would most likely be in a weld which tends to be thicker than the pipe wall. A crack depth of 0.16 inches was therefore assumed to be applicable to either a crack or the more likely case of a misaligned jumper connector.

Consistent with WHC-SD-WM-CN-048, the slurry involved in the spray leak is assumed to contain $33 \%$ entrained solids. This is considered bounding for submersible pumps or saltwell pumps operating near the sludge layer in a tank. It is thought, based on supernate grab samples, that typical transfers contain much less solid content ( $5 \%$ or less). As the solids content decreases, however, the initial droplet size which will evaporate to $10 \mu \mathrm{m}$ or less will increase, thereby increasing the fraction of the initial particle size distribution which will evaporate to respirable size. Because of this competing effect, results are only weakly dependent on this parameter, although a higher solids content will generally produce a worse case.

$$
4 \text { of } 36
$$


The effect of fallout of larger droplets prior to evaporation to respirable size was also investigated. For $33 \%$ solids, droplets with diameters less than or equal to $14.5 \mu \mathrm{m}$ will evaporate to respirable size. For $10 \%$ solids, the droplet size cutoff would increase to $21.5 \mu \mathrm{m}$. For a given temperature and partial pressure of the vapor, the rate of decrease in surface area of a volatile liquid droplet in air is a constant independent of droplet size (Hinds 1982). Thus the rate of shrinkage will be relatively slow for large droplets, but will increase as the droplet size decreases. For very small droplets (less than $1 \mu \mathrm{m}$ ) the evaporation rate becomes 1 imited by the maximum rate of diffusion of vapor away from the droplet. For large droplets (greater than $50 \mu \mathrm{m})$, the gravitational fall velocity adds an effective air velocity relative to the droplet that increases the rate of evaporation. In all cases the effect of cooling due to the latent heat of evaporation must be taken into account. The droplet sizes of concern here are intermediate and thus require only the cooling correction. The lifetime of a $20 \mu \mathrm{m}$ water droplet in air at $20^{\circ} \mathrm{C}$ and $50 \%$ relative humidity is about $1 \mathrm{~s}$ (Hinds 1982) corresponding to a few $\mathrm{cm}$ of fall in the first few meters of travel. There does not seem to be any basis, therefore, for making any additional correction due to gravitational fallout of aerosol particles with an initial diameter greater than $10 \mu \mathrm{m}$ given the effective release height of 50 to $100 \mathrm{~cm}$ typically assumed for this type of release.

\section{Consequence Methodology:}

Radiological and toxicological consequences of releases from the 200 Area Tank Farms are calculated using radiological dose and toxic exposure conversion factors developed in WHC-SD-WM-SARR-037, Development of Radiological Concentrations and Unit Liter Doses for TWRS FSAR Radiological Consequence Calculations (Cowley 1996) and WHC-SD-WM-SARR-011, Toxic Chemical Considerations for Tank Farm Releases (Van Keuren 1996b). Unit Liter Doses (ULD) for Double-Shell Tank (DST) and Aging Waste Facility (AWF) solids and liquids developed in WHC-SD-WM-SARR-037 are shown in Table 2 along with the resulting ULDs for corresponding slurries composed of $33 \%$ solids and $67 \%$ liquid.

Table 2: Unit Liter Doses (ULD) for DST and AWF waste components and $33 \%$ solids slurry

\begin{tabular}{|c|c|c|}
\hline Waste Component & $\begin{array}{l}\text { Inhalation } \\
\text { ULD }(\mathrm{SV} / \mathrm{L})\end{array}$ & $\mathrm{ULD} \stackrel{\text { Ingestion }}{(\mathrm{SV} \cdot \mathrm{m} 3 / \mathrm{s} \cdot \mathrm{L})}$ \\
\hline $\begin{array}{r}\text { Double-Shel1 Tank Liquids } \\
\text { Solids } \\
\text { Slurry }\end{array}$ & $\begin{array}{l}6.1 \mathrm{E}+3 \\
5 \cdot 3 \mathrm{E}+5 \\
1.8 \mathrm{E}+5\end{array}$ & $\begin{array}{l}6.8 \mathrm{E}-2 \\
4.8 \mathrm{E}-1 \\
2.0 \mathrm{E}-1\end{array}$ \\
\hline $\begin{array}{r}\text { Aging Waste Facility Liquids } \\
\text { Solids } \\
\text { Slurry }\end{array}$ & $\begin{array}{l}1.4 \mathrm{E}+3 \\
1.7 \mathrm{E}+6 \\
5.6 \mathrm{E}+5\end{array}$ & $\begin{array}{l}9.2 \mathrm{E}-2 \\
8.1 \mathrm{E}+0 \\
2.7 \mathrm{E}+0\end{array}$ \\
\hline
\end{tabular}


These ULDs are used to calculate onsite and offsite receptor radiological doses using the following formulas. All doses are 50-year committed effective dose equivalents (CEDE). Ingestion doses are for a 24-hour uptake period by the offsite receptor immediately after the passage of the plume assuming a 24 hour delay before evacuation and/or interdiction of food supplies.

For onsite and offsite inhalation doses:

$$
D_{\text {inh }}=(Q)\left(X / Q^{\prime}\right)(B R)\left(U^{\prime} D_{i n h}\right)
$$

And for offsite ingestion doses:

$$
D_{\text {ing }}=(Q)\left(X / Q^{\prime}\right)\left(U L D_{\text {ing }}\right)
$$

Where

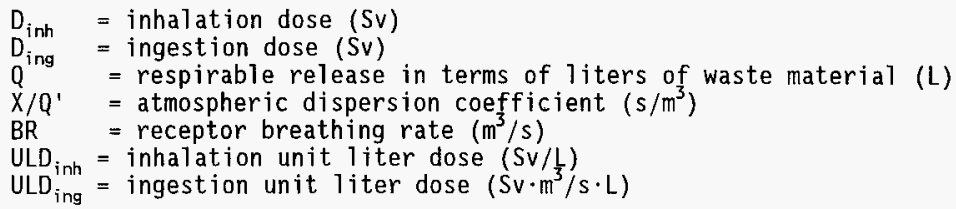

For reasonably constant rate releases with a duration or exposure time less than 24 hours, the light activity breathing rate of $3.3 \mathrm{E}-4 \mathrm{~m}^{3} / \mathrm{s}$ is assumed. For the offsite receptor exposed to a release with duration equal or greater than 24 hours, a 24 -hour average breathing rate of $2.7 \mathrm{E}-4 \mathrm{~m}^{3} / \mathrm{s}$ is normally as sumed.

Toxicological exposure units were developed in WHC-SD-WM-SARR-011 in terms of a sum-of-fractions per unit release rate $(\mathrm{L} / \mathrm{s})$. This parameter already contains the receptor $X / Q^{\prime}(1 \mathrm{~h})$ and the chemical component limits associated with a particular accident frequency. Since the sum of fractions is directly proportional to the $X / Q^{\prime}$, it can be easily corrected for plume fallout by using the ratios of the 1 -hour $X / Q^{\prime}$ s shown in Table 1 . The frequency for all three scenarios considered here has been designated as anticipated with a frequency range of $1-10^{-2} / y$. Unit release rate sums of fractions for DST waste given in WHC-SD-WM-SARR-01l for continuous releases are shown in Table 3 along with the same sums of fractions corrected for plume depletion by deposition. Unit release rate sums of fractions are also shown for a $33 \%$ solids fraction slurry. AWF waste was found in WHC-SD-WM-SARR-011 to have the same toxic effects as DST waste. 
Table 3: Unit release rate toxicological sums of fractions for DST or AWF waste components and $33 \%$ solids slurry for anticipated accident frequency $\left(1-10^{-2} / y\right)$

\begin{tabular}{|c|c|c|c|}
\hline \multirow[b]{2}{*}{ Receptor } & \multirow[b]{2}{*}{ Waste Component } & \multicolumn{2}{|c|}{ Sum of Fractions $(s / L)$} \\
\hline & & $\begin{array}{l}\text { Without } \\
\text { Deposition }\end{array}$ & $\begin{array}{c}\text { With } \\
\text { Deposition }\end{array}$ \\
\hline Onsite & $\begin{array}{ll}\text { Double-She11 } & \text { Liquids } \\
\text { or AWF } & \text { Solids } \\
& \text { Slurry }\end{array}$ & $\begin{array}{l}1.0 \mathrm{E}+4 \\
1.8 \mathrm{E}+4 \\
1.3 \mathrm{E}+4\end{array}$ & $\begin{array}{l}8 \cdot 5 \mathrm{E}+3 \\
1.5 \mathrm{E}+4 \\
1.1 \mathrm{E}+4\end{array}$ \\
\hline Offsite & $\begin{array}{ll}\text { Double-She11 Liquids } \\
\text { or AWF } & \text { Solids } \\
& \text { Slurry }\end{array}$ & $\begin{array}{l}8.4 \mathrm{E}+0 \\
1.9 \mathrm{E}+2 \\
6.8 \mathrm{E}+1\end{array}$ & $\begin{array}{l}4.8 \mathrm{E}+0 \\
1.1 \mathrm{E}+2 \\
3.9 \mathrm{E}+1\end{array}$ \\
\hline
\end{tabular}

\section{Unmitigated Release Results:}

In this case, the cover blocks are assumed to be removed from the pit and the leak is assumed to spray directly into the air above the pit. Since the assumed leak has a relatively low total volume rate (although it maximizes the respirable release rate), and an undetermined amount of material may fall outside the pit, no credit is taken for operation of the the leak detector. The leak is therefore assumed to continue at a constant rate for 24 hours. The site boundary receptor is assumed to be exposed for the entire passage of the plume. The onsite receptor is exposed for 12 hours (1 shift plus overtime).

The respirable release rate is dependent only on the leak parameters, and not on the size of the pit. The bounding consequences for the unmitigated case are therefore produced by assuming AWF slurry. The respirable aerosol release rate was produced by optimizing the width of the assumed 2 inch-long slit using the SPRAY code. The optimum slit width is $4.55 \mathrm{E}-3$ inches $(1.16 \mathrm{E}-1 \mathrm{~mm})$ resulting in a maximum respirable release rate of $2.28 \mathrm{E}-3 \mathrm{~L} / \mathrm{s}\left(2.28 \mathrm{E}-6 \mathrm{~m}^{3} / \mathrm{s}\right)$ corresponding to a total volume flow rate of $1.41 \mathrm{E}-4 \mathrm{~m}^{3} / \mathrm{s}(2.24 \mathrm{gpm})$. (The SPRAY code input/output file for this case is included as Attachment 2.) The total 24 hour release is therefore $197 \mathrm{~L}$, while for 12 hours the release is $98.5 \mathrm{~L}$. (The effect of reducing the solids content of the slurry to $10 \%$ was investigated with the result that the respirable release rate increased by about a factor of 3 for reasons previously discussed [see second run file in Attachment 2], while the ULD decreased by about a factor of 3.3. The net change would be a small reduction in dose.)

It has been suggested that, due to the strong smell associated with this caustic slurry and the amount released, the onsite receptor at $100 \mathrm{~m}$ would immediately realize that a release was occurring and move cross-wind out of the plume. Consequences for the onsite receptor were therefore also calculated assuming self-evacuation after 10 minutes. The respirable release for the 10-minute exposure is $1.37 \mathrm{~L}$. 
$\Rightarrow$ Radiological consequences:

The 24-hour offsite radiological doses are therefore as follows:

$$
\begin{aligned}
\mathrm{D}_{\text {inh }} & =(197 \mathrm{~L})\left(2.75 \mathrm{E}-6 \mathrm{~s} / \mathrm{m}^{3}\right)\left(2.7 \mathrm{E}-4 \mathrm{~m}^{3} / \mathrm{s}\right)(5.6 \mathrm{E}+5 \mathrm{SV} / \mathrm{L}) \\
& =8.19 \mathrm{E}-2 \mathrm{SV} \quad(8.19 \mathrm{E}+0 \mathrm{rem}) \\
\mathrm{D}_{\text {ing }} & =(197 \mathrm{~L})\left(2.75 \mathrm{E}-6 \mathrm{~s} / \mathrm{m}^{3}\right)\left(2.7 \mathrm{sv} \cdot \mathrm{m}^{3} / \mathrm{s} \cdot \mathrm{L}\right) \\
& =1.46 \mathrm{E}-3 \mathrm{SV} \quad(1.46 \mathrm{E}-1 \mathrm{rem})
\end{aligned}
$$

Total 24-hour offsite dose is then $8.34 \mathrm{E}-2 \mathrm{~Sv}(8.34 \mathrm{E}+0$ rem).

The 12-hour onsite dose is given by:

$$
\begin{aligned}
D_{i n h} & =(98.5 \mathrm{~L})\left(5.15 \mathrm{E}-3 \mathrm{~s} / \mathrm{m}^{3}\right)\left(3.3 \mathrm{E}-4 \mathrm{~m}^{3} / \mathrm{s}\right)(5.6 \mathrm{E}+5 \mathrm{sv} / \mathrm{L}) \\
& =9.37 \mathrm{E}+1 \mathrm{SV} \quad(9.37 \mathrm{E}+3 \mathrm{rem})
\end{aligned}
$$

The 10-minute onsite dose (assuming self-evacuation after 10 minutes) is given by:

$$
\begin{aligned}
D_{i n h} & =(1.37 \mathrm{~L})\left(2.91 \mathrm{E}-2 \mathrm{~s} / \mathrm{m}^{3}\right)\left(3.3 \mathrm{E}-4 \mathrm{~m}^{3} / \mathrm{s}\right)(5.6 \mathrm{E}+5 \mathrm{SV} / \mathrm{L}) \\
& =7.37 \mathrm{E}+0 \mathrm{SV} \quad(7.37 \mathrm{E}+2 \mathrm{rem})
\end{aligned}
$$

$\Rightarrow$ Toxicological consequences:

The toxicological sum of fractions is simply the appropriate unit release sum of fractions given in Table 3 times the respirable slurry release rate of $2.28 \mathrm{E}-3 \mathrm{~L} / \mathrm{s}$. The onsite sum of fractions is then $(1.1 \mathrm{E}+4 \mathrm{~s} / \mathrm{L})(2.28 \mathrm{E}-3 \mathrm{~L} / \mathrm{s})=$ $2.51 E+1$ whether or not self-evacuation is assumed. The offsite sum of fractions is $(3.9 \mathrm{E}+1 \mathrm{~s} / \mathrm{L})(2.28 \mathrm{E}-3 \mathrm{~L} / \mathrm{s})=8.89 \mathrm{E}-2$.

For this slurry mix (using the information in Appendix E of WHC-SD-WM-SARR011 ), about $50 \%$ of the sum of fractions is due to $\mathrm{NaOH}$. A sum of fractions of 25 for the onsite receptor therefore corresponds to a $\mathrm{NaOH}$ concentration roughly 12 times the ERPG- 1 i imit of $2 \mathrm{mg} / \mathrm{m}^{3}$ for the onsite receptor and an accident frequency in this range. This would place the $\mathrm{NaOH}$ concentration well below the ERPG-2 $\left(40 \mathrm{mg} / \mathrm{m}^{3}\right)$ limit where the ability to take protective action would not be effected. At this kind of concentration, the onsite receptor would know immediately that something was seriously wrong, and would probably try to get out of the plume very quickly (on the order of minutes). 


\section{DST Slurry mitigated Release Results:}

The 1 argest active pit is the 241-AP valve pit with outside dimensions of 61 $\mathrm{ft} \times 16 \mathrm{ft} \times 8 \mathrm{ft}$ deep. The cover on this pit is $2.17 \mathrm{ft}$ thick, the bottom $1.33 \mathrm{ft}$ thick and the walls are $1 \mathrm{ft}$ thick (DOE 1991). In addition there is a 16-ft walled-off space at one end of the pit which serves for equipment storage. The net interior dimensions of the space accessible to a spray leak are then $42 \mathrm{ft} \times 14 \mathrm{ft} \times 4.5 \mathrm{ft}$ deep with a total volume of $2650 \mathrm{ft}^{3}$ or 74.9 $\mathrm{m}^{3}$.

Although it is expected that a 1 -inch accumulation of water in the bottom of the pit will activate the leak detector, it is assumed here, consistent with WHC-SD-WM-CN-049, Calculation Notes for Surface Leak Resulting in Pool, TWRS FSAR Accident Analysis (Hall 1996b), that an accumulation of 2 inches of water in the bottom of the pit is required to set off the leak detector, and that there follows a response time of 30 minutes before the transfer pump is stopped. The volume of a 2 -inch layer of liquid on the bottom of the pit is $98.0 \mathrm{ft}^{3}$ or $2.78 \mathrm{~m}^{3}$.

The driving force for release of material to the envronment in this case is the displacement of air with entrained aerosol through gaps and crevices in and around the cover blocks. The displaced air is assumed to be mixed with the maximum quasi-stable aerosol loading of $100 \mathrm{mg} / \mathrm{m}^{3}$ (Hall 1996a, ANSI N46.1 1980). The aerosol generation rate of the spray leak is therefore not important since the excess air loading will simply fall out or plate out onto surfaces within the pit. The operative factors here are the volume of air displaced out of the pit and the release time. As a worst case it is assumed that the pit drain is closed to maximize air dispacement out of the pit.

Two leak volume rates were investigated. A low volume leak, such as the one previously assumed for the unmitigated spray release, would displace less air out of the pit, but would take a longer time to set off the leak detector. A high volume rate leak, on the other hand, would displace more air, but would decrease the release duration because the leak detector would be set off sooner. In either case, there is an initial expansion of the air in the pit due to an assumed increase in air temperature and relative humidity from $30^{\circ} \mathrm{F}$ at $15 \%$ R.H. to $120^{\circ} \mathrm{F}$ at $100 \%$ R.H. leading to a release of $35 \%$ of the total pit volume $(\mathrm{Hall} 1996 \mathrm{a})$. The initial release volume is then $(0.35)\left(74.9 \mathrm{~m}^{3}\right)=$ $26.2 \mathrm{~m}^{3}$. The time required to perform the initial heat-up and expansion of the pit air is uncertain, but is assumed to be less than 1 hour.

The high efficiency, low volume rate leak previously assumed for the unmitigated case was assumed here for the limiting low volume leak. Recall that the total spray volume rate was $1.41 \mathrm{E}-4 \mathrm{~m}^{3} / \mathrm{s}$. The time required to set off the leak detector is therefore $\left(2.78 \mathrm{~m}^{3}\right) /\left(1.41 \mathrm{E}-4 \mathrm{~m}^{3} / \mathrm{s}\right)=1.97 \mathrm{E}+4 \mathrm{~s}$ or 5.48 hours. The response time to secure the transfer pump is an additional 30 minutes leading to a total release duration of 6.0 hours. The air volume displaced from the pit by inleaking liquid in 6.0 hours is $(6.0 \mathrm{~h})(3600$ $\mathrm{s} / \mathrm{h})\left(1.41 \mathrm{E}-4 \mathrm{~m}^{3} / \mathrm{s}\right)=3.05 \mathrm{~m}^{3}$ for a total of $29.3 \mathrm{~m}^{3}$ including the initial expansion. The accompanying slurry release is therefore $\left(29.3 \mathrm{~m}^{3}\right)\left(0.1 \mathrm{~g} / \mathrm{m}^{3}\right)=$ $2.93 \mathrm{~g}$ or $2.09 \mathrm{E}-3 \mathrm{~L}$ of $1.4 \mathrm{~g} / \mathrm{cm}^{3}$ slurry. 
The high volume rate leak is assumed to be of such a size that the leak detector alarms after 30 minutes. This produces a total release time of one hour, minimizing dispersion in transjt and, therefore, maximizing doses. The required volume rate is then $\left(2.78 \mathrm{~m}^{3}\right)(1800 \mathrm{~s})=1.54 \mathrm{E}-3 \mathrm{~m}^{3} / \mathrm{s}$ or $24.5 \mathrm{gpm}$. Although a leak of this size would not be very efficient at generating respirable aerosol, it would probably generate enough to keep the air within the closed pit saturated. With a 30 minute response time, the leak duration is 1.0 hours, which is also assumed to be sufficient time for the injtial air expansion to occur. The fluid displaced air in 1 hour is $\left(1.54 \mathrm{E}-3 \mathrm{~m}^{3} / \mathrm{s}\right)(3600$ $s)=5.54 \mathrm{~m}^{3}$ for a total displacement from the pit of $31.7 \mathrm{~m}^{3}$ including the initial air expansion. The air leaving the pit will then contain $2.27 \mathrm{E}-3 \mathrm{~L}$ of slurry released over 1 hour. Note that this is somewhat more volume than was released by the low volume rate spray. There is little difference, however, since the bulk of the release is due to the initial air expansion. For the same reason, evacuation of the onsite receptor would produce little benefit in this case.

In addition a case was developed for comparison purposes in which it is assumed that the leak detector fails to function. Consistent with WHC-SD-WMCN-048 (Hall 1996a), the spray leak is assumed to be just covered with liquid when the pit is half full. The pit will fill half full in a time given by $\left(37.5 \mathrm{~m}^{3}\right) /\left(1.54 \mathrm{E}-3 \mathrm{~m}^{3} / \mathrm{s}\right)=2.44 \mathrm{E}+4 \mathrm{~s}$ or 6.8 hours. For some time after the leak is covered there may be sufficient liquid aggitation to generate some aerosol, and some additional time will be required for the air in the pit to become depleted of material. The release is therefore conservatively assumed to continue for a total duration of 8 hours. This release is actually composed of two superimposed releases: a short release due to the initial air expansion; and an 8-hour release due to air displacement due to inflow of liquid into the pit. The short (1 hour for analysis purposes) release is 26.2 $\mathrm{m}^{3}$ of air carrying $1.87 \mathrm{E}-3 \mathrm{~L}$ of slurry, while the longer release is given by $1.54 \mathrm{E}-3 \mathrm{~m}^{3} / \mathrm{s}$ displacement rate for 8 hours or $4.44 \mathrm{E}+1 \mathrm{~m}^{3}$ corresponding to $3.17 \mathrm{E}-3 \mathrm{~L}$ of slurry. Since these two releases involve different dispersion averaging times, they must be treated separately and the resulting radiological doses added.

$\Rightarrow$ Radiological Consequences:

The 1-hour offsite radiological doses (with leak detector) are as follows. Note that, due to the short release duration, the active breathing rate is used for the offsite receptor, as well as onsite.

$$
\begin{aligned}
D_{i n h} & =(2.27 \mathrm{E}-3 \mathrm{~L})\left(1.61 \mathrm{E}-5 \mathrm{~s} / \mathrm{m}^{3}\right)\left(3.3 \mathrm{E}-4 \mathrm{~m}^{3} / \mathrm{s}\right)(1.8 \mathrm{E}+5 \mathrm{~Sv} / \mathrm{L}) \\
& =2.17 \mathrm{E}-6 \mathrm{SV}(2.17 \mathrm{E}-4 \mathrm{rem}) \\
D_{\text {ing }} & =(2.27 \mathrm{E}-3 \mathrm{~L})\left(1.61 \mathrm{E}-5 \mathrm{~s} / \mathrm{m}^{3}\right)\left(2.0 \mathrm{E}-1 \mathrm{~Sv} \cdot \mathrm{m}^{3} / \mathrm{s} \cdot \mathrm{L}\right) \\
& =7.31 \mathrm{E}-9 \mathrm{SV} \quad(7.31 \mathrm{E}-7 \mathrm{rem})
\end{aligned}
$$

Total offsite dose is then $2.18 \mathrm{E}-6 \mathrm{~Sv}(2.18 \mathrm{E}-4 \mathrm{rem})$. 
The 1-hour onsite dose is given by

$$
\begin{aligned}
D_{\text {inh }} & =(2.27 \mathrm{E}-3 \mathrm{~L})\left(2.91 \mathrm{E}-2 \mathrm{~s} / \mathrm{m}^{3}\right)\left(3.3 \mathrm{E}-4 \mathrm{~m}^{3} / \mathrm{s}\right)(1.8 \mathrm{E}+5 \mathrm{SV} / \mathrm{L}) \\
& =3.92 \mathrm{E}-3 \mathrm{SV} \quad(3.92 \mathrm{E}-1 \mathrm{rem})
\end{aligned}
$$

The 8-hour offsite radiological doses (no leak detector function) are as follows. Note that, due to the short release duration, the active breathing rate is used for the offsite receptor, as well as onsite. Note also that the 1-hour and 8-hour releases are separated.

$$
\begin{aligned}
& \begin{aligned}
D_{\text {inh }}= & {\left[(1.87 \mathrm{E}-3 \mathrm{~L}) \frac{\mathrm{s}}{3}\left(1.61 \mathrm{E}-5 \mathrm{~s} / \mathrm{m}^{3}\right)+(3.17 \mathrm{E}-3 \mathrm{~L})\left(5.28 \mathrm{E}-6 \mathrm{~s} / \mathrm{m}^{3}\right)\right] } \\
& \left(3.3 \mathrm{E}-4 \mathrm{~m}^{3} / \mathrm{s}\right)(1.8 \mathrm{E}+5 \mathrm{SV} / \mathrm{L})
\end{aligned} \\
& =2.78 \mathrm{E}-6 \mathrm{SV} \quad(2.78 \mathrm{E}-4 \mathrm{rem})
\end{aligned}
$$

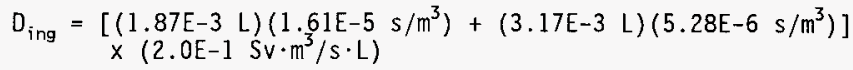

$$
\begin{aligned}
& =9.37 \mathrm{E}-9 \mathrm{SV} \quad(9.37 \mathrm{E}-7 \text { rem) }
\end{aligned}
$$

Total offsite dose is then 2.79E-6 Sv (2.79E-4 rem). The 8-hour onsite dose is given by

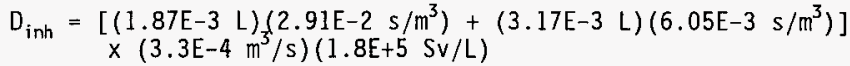

$$
\begin{aligned}
& =4.37 \mathrm{E}-3 \mathrm{SV} \quad(4.37 \mathrm{E}-1 \mathrm{rem})
\end{aligned}
$$

$==>$ Toxicological consequences:

The toxicological sum of fractions is simply the appropriate unit release sum of fractions given in Table 3 times the maximum respirable slurry release rate. The total release from initial air expansion is $26.2 \mathrm{~m}^{3}$ which carries $1.87 \mathrm{E}-3 \mathrm{~L}$ of slurry. Conservatively assuming the expansion takes place in the first 15 minutes, produces a release rate of $2.08 \mathrm{E}-6 \mathrm{~L} / \mathrm{s}$. The release rate due to ajr displacement from inflow of liquid is $\left(1.54 \mathrm{E}-3 \mathrm{~m}^{3} / \mathrm{s}\right)$

$\left(0.1 \mathrm{~g} / \mathrm{m}^{3}\right)\left(1 / 1.4 \mathrm{~g} / \mathrm{cm}^{3}\right)\left(1 \mathrm{E}-3 \mathrm{~L} / \mathrm{cm}^{3}\right)=1.10 \mathrm{E}-7 \mathrm{~L} / \mathrm{s}$. The total slurry release rate is therefore $2.19 \mathrm{E}-6 \mathrm{~L} / \mathrm{s}$ independent of whether or not the leak detector works.

The onsite sum of fractions is then $(1.1 \mathrm{E}+4 \mathrm{~s} / \mathrm{L})(2.19 \mathrm{E}-6 \mathrm{~L} / \mathrm{s})=2.4 \mathrm{E}-2$. The offsite sum of fractions is $(3.9 \mathrm{E}+1 \mathrm{~s} / \mathrm{L})(2.19 \mathrm{E}-6 \mathrm{~L} / \mathrm{s})=8.5 \mathrm{E}-5$.

\section{AWF Slurry Mitigated Release Results:}

The largest active pit through which AWF slurry can be transferred is the 241AP valve pit with outside dimensions of $18 \mathrm{ft} \times 11 \mathrm{ft} \times 6.5 \mathrm{ft}$ deep. The cover on this pit is $2.5 \mathrm{ft}$ thick, the bottom $1 \mathrm{ft}$ thick and the walls are 1.5 
$\mathrm{ft}$ thick (DOE 1991). The net interior dimensions are then $15 \mathrm{ft} \times 8 \mathrm{ft} \times 3 \mathrm{ft}$ deep with a total volume of $360 \mathrm{ft}^{3}$ or $10.2 \mathrm{~m}^{3}$.

Although it is expected that a 1-inch accumulation of water in the bottom of the pit will activate the leak detector, it is assumed here, consistent with WHC-SD-WM-CN-049, Calculation Notes for Surface Leak Resulting in Poo7, TWRS FSAR Accident Analysis (Hall 1996b), that an accumulation of 2 inches of water in the bottom of the pit is required to set off the leak detector, and that there follows a response time of 30 minutes before the transfer pump is stopped. The volume of a 2 -inch layer of 1 iquid on the bottom of the pit is $20.0 \mathrm{ft}^{3}$ or $0.566 \mathrm{~m}^{3}$.

The driving force for release of material to the envronment in this case is the displacement of air with entrained aerosol through gaps and crevices in and around the cover block. The displaced air is assumed to be mixed with the maximum quasi-stable aerosol loading of $100 \mathrm{mg} / \mathrm{m}^{3}$ (Hall $1996 \mathrm{a}$, ANSI N46.1 1980 ). The aerosol generation rate of the spray leak is therefore not important since the excess air loading will simply fall out or plate out onto surfaces within the pit. The operative factors here are volume of air displaced out of the pit and the release time. As a worst case it is assumed that the pit drain is closed.

Two leak volume rates were investigated as before. A low volume leak, such as the one previously assumed for the unmitigated spray release, would displace less air out of the pit, but would take a longer time to set off the leak detector. A high volume rate leak, on the other hand, would displace more air, but would decrease the release duration because the leak detector would be set off sooner. In either case, there is an initial expansion of the air in the pit due to an assumed increase in air temperature and relative humidity from $30^{\circ} \mathrm{F}$ at $15 \%$ R.H. to $120^{\circ} \mathrm{F}$ at $100 \%$ R.H. leading to a release of $35 \%$ of the total pit volume (Hall 1996a). The initial release volume is then $(0.35)(10.2$ $\left.\mathrm{m}^{3}\right)=3.57 \mathrm{~m}^{3}$. The time required to perform the initial heat-up and expansion of the pit air is uncertain, but is assumed to be less than 1 hour.

The high efficiency, low volume rate leak previously assumed for the unmitigated case was assumed here for the limiting low volume leak. Recall that the total spray volume rate was $1.41 \mathrm{E}-4 \mathrm{~m}^{3} / \mathrm{s}$. The time required to set off the leak detector is therefore $\left(0.566 \mathrm{~m}^{3}\right) /\left(1.41 \mathrm{E}-4 \mathrm{~m}^{3} / \mathrm{s}\right)=4.02 \mathrm{E}+3 \mathrm{~s}$ or 1.12 hours. The response time to secure the transfer pump is an additional 30 minutes leading to a total release duration of 1.6 hours. The air volume displaced from the pit by inleaking liquid in 1.6 hours is $(1.6 \mathrm{~h})(3600$ $\mathrm{s} / \mathrm{h})\left(1.41 \mathrm{E}-4 \mathrm{~m}^{3} / \mathrm{s}\right)=0.820 \mathrm{~m}^{3}$ for a total of $4.39 \mathrm{~m}^{3}$ including the initial expansion. The accompanying slurry release is therefore $\left(4.39 \mathrm{~m}^{3}\right)\left(0.1 \mathrm{~g} / \mathrm{m}^{3}\right)=$ $4.39 \mathrm{E}-1 \mathrm{~g}$ or $3.14 \mathrm{E}-4 \mathrm{~L}$ of $1.4 \mathrm{~g} / \mathrm{cm}^{3}$ slurry.

As before, the high volume rate leak is assumed to be of such a size that the leak detector alarms after 30 minutes. The required volume rate is then $\left(0.566 \mathrm{~m}^{3}\right) /(1800 \mathrm{~s})=3.14 \mathrm{E}-4 \mathrm{~m}^{3} / \mathrm{s}$ or $4.98 \mathrm{gpm}$. With a 30 minute response time, the leak duration is 1.0 hours, which is also assumed to be sufficient time for the initial air expansion to occur. The fluid displaced air in 1 hour is $\left(3.14 \mathrm{E}-4 \mathrm{~m}^{3} / \mathrm{s}\right)(3600 \mathrm{~s})=1.13 \mathrm{~m}^{3}$ for a total displacement from the pit of $4.70 \mathrm{~m}^{3}$ including the initial air expansion. The air leaving the pit will then contain $3.36 \mathrm{E}-4 \mathrm{~L}$ of slurry released over 1 hour. Note that this is 
somewhat more volume than was released by the low volume rate spray. There is little difference, however, since the bulk of the release is due to the initial air expansion. For the same reason, evacuation of the onsite receptor would produce little benefit in this case.

In addition a case was developed for comparison purposes in which it is assumed that the leak detector fails to function. Consistent with WHC-SD-WMCN-048 (Hall 1996a), the spray leak is assumed to be just covered with liquid when the pit is half full. The pit will fill half full in a time given by $\left(5.10 \mathrm{~m}^{3}\right) /\left(3.14 \mathrm{E}-4 \mathrm{~m}^{3} / \mathrm{s}\right)=1.62 \mathrm{E}+4 \mathrm{~s}$ or 4.5 hours. For some time after the leak is covered there may be sufficient 1 iquid aggitation to generate some aerosol, and some additional time will be required for the air in the pit to become depleted of material. The release is therefore conservatively assumed to continue for a total duration of 6 hours. This release is actually composed of two superimposed releases: a short release due to the initial air expansion; and an 6-hour release due to air displacement due to inflow of liquid into the pit. The short (1 hour for analys is purposes) release is 3.57 $\mathrm{m}^{3}$ of air carrying $2.55 \mathrm{E}-4 \mathrm{~L}$ of slurry, while the longer release is given by $3.14 \mathrm{E}-4 \mathrm{~m}^{3} / \mathrm{s}$ displacement rate for 6 hours or $6.78 \mathrm{E}+0 \mathrm{~m}^{3}$ corresponding to 4.84E-4 $\mathrm{L}$ of slurry. Since these two releases involve different dispersion averaging times, they must be treated separately and the resulting radiological doses added.

$==>$ Radiological Consequences:

The 1-hour offsite radiological doses (with leak detector) are as follows. Note that, due to the short release duration, the active breathing rate is used for the offsite receptor, as well as onsite.

$$
\begin{aligned}
D_{i n h} & =(3.36 \mathrm{E}-4 \mathrm{~L})\left(1.61 \mathrm{E}-5 \mathrm{~s} / \mathrm{m}^{3}\right)\left(3.3 \mathrm{E}-4 \mathrm{~m}^{3} / \mathrm{s}\right)(5.6 \mathrm{E}+5 \mathrm{~Sv} / \mathrm{L}) \\
& =1.00 \mathrm{E}-6 \mathrm{SV} \quad(1.00 \mathrm{E}-4 \mathrm{rem}) \\
D_{\text {ing }} & =(3.36 \mathrm{E}-4 \mathrm{~L})\left(1.61 \mathrm{E}-5 \mathrm{~s} / \mathrm{m}^{3}\right)\left(2.7 \mathrm{E}+0 \mathrm{sv} \cdot \mathrm{m}^{3} / \mathrm{s} \cdot \mathrm{L}\right) \\
& =1.46 \mathrm{E}-8 \mathrm{SV} \quad(1.46 \mathrm{E}-6 \mathrm{rem})
\end{aligned}
$$

Total offsite dose is then $1.01 \mathrm{E}-6 \mathrm{~Sv}(1.01 \mathrm{E}-4 \mathrm{rem})$.

The 1-hour onsite dose is given by

$$
\begin{aligned}
D_{i n h} & =(3.36 \mathrm{E}-4 \mathrm{~L})\left(2.91 \mathrm{E}-2 \mathrm{~s} / \mathrm{m}^{3}\right)\left(3.3 \mathrm{E}-4 \mathrm{~m}^{3} / \mathrm{s}\right)(5.6 \mathrm{E}+5 \mathrm{SV} / \mathrm{L}) \\
& =1.81 \mathrm{E}-3 \mathrm{SV} \quad(1.81 \mathrm{E}-1 \mathrm{rem})
\end{aligned}
$$

The 6-hour offsite radiological doses (no leak detector function) are as follows. Note that, due to the short release duration, the active breathing rate is used for the offsite receptor, as well as onsite. Note also that the 1-hour and 6-hour releases are separated. 


$$
\begin{aligned}
& \left.D_{i n h}=\underset{x\left(3.3 E-4 \mathrm{~m}^{3} / \mathrm{s}\right)(5.6 \mathrm{E}+5 \mathrm{sv} / \mathrm{L})}{[(2.55 \mathrm{E}-4 \mathrm{~L})}(1.61 \mathrm{E}-5 \mathrm{~m})+(4.84 \mathrm{E}-4 \mathrm{~L})\left(6.26 \mathrm{E}-6 \mathrm{~s} / \mathrm{m}^{3}\right)\right] \\
& =1.32 \mathrm{E}-6 \text { SV } \quad(1.32 \mathrm{E}-4 \text { rem }) \\
& \left.D_{\text {ing }}=\underset{x\left(2.7 E+0 S V \cdot \mathrm{m}^{3} / \mathrm{s} \cdot \mathrm{L}\right)}{\left[\left(2.55 \mathrm{E}-4 \mathrm{~s} / \mathrm{m}^{3}\right)\right.}+(1.84 \mathrm{E}-4 \mathrm{~L})\left(6.26 \mathrm{E}-6 \mathrm{~s} / \mathrm{m}^{3}\right)\right] \\
& =1.93 \mathrm{E}-8 \mathrm{SV} \quad(1.93 \mathrm{E}-6 \mathrm{rem})
\end{aligned}
$$

Total offsite dose is then $1.34 \mathrm{E}-6 \mathrm{SV}$ (1.34E-4 rem).

The 6-hour onsite dose is given by

$$
\begin{aligned}
D_{i n h}= & {\left[(2.55 E-4 L)\left(2.91 E-2 \mathrm{~s} / \mathrm{m}^{3}\right)+(4.84 E-4 L)\left(6.79 E-3 \mathrm{~s} / \mathrm{m}^{3}\right)\right] } \\
& x\left(3.3 \mathrm{E}-4 \mathrm{~m}^{3} / \mathrm{s}\right)(5.6 \mathrm{E}+5 \mathrm{SV} / \mathrm{L}) \\
= & 1.98 \mathrm{E}-3 \mathrm{SV} \quad(1.98 \mathrm{E}-1 \mathrm{rem})
\end{aligned}
$$

$\Rightarrow$ Toxicological consequences:

The toxicological sum of fractions is simply the appropriate unit release sum of fractions given in Table 3 times the respirable slurry release rate. The total release from initial air expansion is $3.57 \mathrm{~m}^{3}$ which carries $2.55 \mathrm{E}-4 \mathrm{~L}$ of slurry. Conservatively assuming the expansion takes place in the first 15 minutes, produces a release rate of $2.83 \mathrm{E}-7 \mathrm{~L} / \mathrm{s}$. The release rate due to air displacement from inflow of liquid is $\left(3.14 \mathrm{E}-4 \mathrm{~m}^{3} / \mathrm{s}\right)\left(0.1 \mathrm{~g} / \mathrm{m}^{3}\right)\left(1 / 1.4 \mathrm{~g} / \mathrm{cm}^{3}\right)$ $\left(1 \mathrm{E}-3 \mathrm{~L} / \mathrm{cm}^{3}\right)=2.24 \mathrm{E}-8 \mathrm{~L} / \mathrm{s}$. The total maximum slurry release rate is therefore $3.06 \mathrm{E}-7 \mathrm{~L} / \mathrm{s}$.

The onsite sum of fractions is then $(1.1 \mathrm{E}+4 \mathrm{~s} / \mathrm{L})(3.06 \mathrm{E}-7 \mathrm{~L} / \mathrm{s})=3.37 \mathrm{E}-3$. The offsite sum of fractions is $(3.9 \mathrm{E}+1 \mathrm{~s} / \mathrm{L})(3.06 \mathrm{E}-7 \mathrm{~L} / \mathrm{s})=1.19 \mathrm{E}-5$.

\section{Conclusion:}

The results of the three spray leak cases are summarized in Tables 4, 5, and 6 . The unmitigated case includes the effect of self-evacuation of the onsite receptor after 10 minutes. Only the onsite radiological dose is affected. The two unmitigated cases include evaluations of consequences with and without a pit leak detector. 
Table 4: Consequences of unmitigated AWF slurry spray leak

\begin{tabular}{|c|c|c|c|c|}
\hline \multirow[b]{2}{*}{ Hazard } & \multirow[b]{2}{*}{ Receptor } & \multicolumn{2}{|c|}{ Dose/Exposure } & \multirow[b]{2}{*}{$\begin{array}{c}\text { Evaluation Guideline } \\
\text { (Anticipated) }\end{array}$} \\
\hline & & $\begin{array}{c}\text { Without } \\
\text { Evacuation }\end{array}$ & $\begin{array}{l}\text { With Self- } \\
\text { Evacuation }\end{array}$ & \\
\hline Radiological & $\begin{array}{l}\text { Offsite } \\
\text { Onsite }\end{array}$ & $\begin{array}{l}83 \mathrm{mSv} \\
94 \mathrm{~Sv}\end{array}$ & $\begin{array}{l}83 \mathrm{mSv} \\
7.4 \mathrm{SV}\end{array}$ & $\begin{array}{l}1 \mathrm{mSv} \\
5 \mathrm{mSv}\end{array}$ \\
\hline Toxicological & $\begin{array}{l}\text { Offsite } \\
\text { Onsite }\end{array}$ & $\begin{array}{l}8.9 \mathrm{E}-2 \\
2.5 \mathrm{E}+1\end{array}$ & $\begin{array}{l}8.9 \mathrm{E}-2 \\
2.5 \mathrm{E}+1\end{array}$ & $\begin{array}{l}1 \\
1\end{array}$ \\
\hline
\end{tabular}

Table 5: Consequences of mitigated DST slurry spray leak

\begin{tabular}{ccccc} 
& & \multicolumn{2}{c}{ Dose/Exposure } & \\
\cline { 3 - 5 } Hazard & Receptor & $\begin{array}{c}\text { With Leak } \\
\text { Detector }\end{array}$ & $\begin{array}{c}\text { Without Leak } \\
\text { Detector }\end{array}$ & $\begin{array}{c}\text { Evaluation Guideline } \\
\text { (Anticipated) }\end{array}$ \\
\hline Radiological & $\begin{array}{l}\text { Offsite } \\
\text { Onsite }\end{array}$ & $\begin{array}{c}0.0022 \mathrm{mSv} \\
3.9 \mathrm{mSV}\end{array}$ & $\begin{array}{c}0.0028 \mathrm{mSv} \\
4.4 \mathrm{mSv}\end{array}$ & $\begin{array}{c}1 \mathrm{mSv} \\
5 \mathrm{mSv}\end{array}$ \\
Toxicological & $\begin{array}{l}\text { Offsite } \\
\text { Onsite }\end{array}$ & $\begin{array}{c}8.5 \mathrm{E}-5 \\
2.4 \mathrm{E}-2\end{array}$ & $\begin{array}{l}8.5 \mathrm{E}-5 \\
2.4 \mathrm{E}-2\end{array}$ & 1 \\
& &
\end{tabular}

Table 6: Consequences of mitigated AWF slurry spray leak

Dose/Exposure

\begin{tabular}{|c|c|c|c|c|}
\hline \multirow[b]{2}{*}{ Hazard } & \multirow[b]{2}{*}{ Receptor } & \multicolumn{2}{|c|}{ Dose/Exposure } & \multirow[b]{2}{*}{$\begin{array}{c}\text { Evaluation Guidel ine } \\
\text { (Anticipated) }\end{array}$} \\
\hline & & $\begin{array}{l}\text { With Leak } \\
\text { Detector }\end{array}$ & $\begin{array}{l}\text { Without Leak } \\
\text { Detector }\end{array}$ & \\
\hline Radiological & $\begin{array}{l}\text { Offsite } \\
\text { Onsite }\end{array}$ & $\begin{array}{l}0.0010 \mathrm{mSv} \\
1.8 \mathrm{mSV}\end{array}$ & $\begin{array}{c}0.0013 \mathrm{mSv} \\
2.0 \mathrm{mSv}\end{array}$ & $\begin{array}{l}1 \mathrm{mSV} \\
5 \mathrm{mSV}\end{array}$ \\
\hline Toxicological & $\begin{array}{l}\text { Offsite } \\
\text { Onsite }\end{array}$ & $\begin{array}{l}1.2 \mathrm{E}-5 \\
3.4 \mathrm{E}-3\end{array}$ & $\begin{array}{l}1.2 \mathrm{E}-5 \\
3.4 \mathrm{E}-3\end{array}$ & $\begin{array}{l}1 \\
1\end{array}$ \\
\hline
\end{tabular}

These radiological doses and toxicological exposures represent a considerable reduction when compared to those originally reported in WHC-SD-CN-048. These reductions are due primarily to corrected (smaller) volumes attributed to the effected transfer pits, use of a more realistic fluid pressure at the leak, and inclusion of the effects of plume depletion due to deposition of particulates in transit to the receptor. Consequences of the mitigated releases are approximately proportional to the volumes of the pits involved. Taking credit for deposition during transit produced a decrease of $7 \%$ to $15 \%$ for the onsite receptor and about $40 \%$ offsite for both the mitigated and unmitigated releases. 
Code Documentation:

GXQ Code version 4.0A (Dec. 19, 1994) (Hey 1994)

Joint Frequency Data File: 200 Area (HMS) - 10 m - Pasquill A - G (1983-1991)

Spray Code version 3.0 (May 3, 1994) (Hey and Leach 1994)

\section{References:}

ANSI N46.1, 1980, American National Standard - Guidance for Defining SafetyRelated Features of Nuclear Fuel Cycle Facilities, American Nuclear Society, La Grange Park, Illinois.

Cowley 1996, W.L. Cowley, Development of Radiological Concentrations and Unit Liter Doses for TWRS FSAR Radiological Consequence Calculations, WHC-SDWM-SARR-037, Apri1 1996.

DOE 1991, DST System Dangerous Waste Permit Application, DOE/RL-90-39 Rev 0, June 1991 .

Hall 1996a, B.W. Hal1, Calculation Notes in Support of TWRS FSAR Spray Leak Accident Analysis, WHC-SD-WM-CN-048 Rev 1, September 1996.

Halt 1996b, B.W. Hal1, Calculation Notes for Surface Leak Resulting in Pool, TWRS FSAR Accident Analysis, WHC-SD-WM-CN-049 Rev 0, September 1996.

Hey 1994, B.E. Hey, GXQ Program User's Guide, WHC-SD-GN-SWD-30002, Rev. 1, December 1994.

Hey and Leach 1994, B.E. Hey and D.S. Leach, A Model for Predicting Respirable Releases from Pressurized Leaks, WHC-SD-GN-SWD-20007 Rev 0, April 1994.

Hinds 1982, William C. Hinds, Aeroso7 Technology - Properties, Behavior, and Measurement of Airborne Particles, John Wiley \& Sons, Inc., 1982.

Napier 1988, B.A. Napier, D.L. Strenge, R.A. Peloquin, and J.V. Ramsdell, GENII - The Hanford Environmental Radiation Dosimetry Software System, PNL-6584, December 1988.

Stupka 1986, R.C. Stupka, G.S. Kephart, and P.D. Rittmann, Environmental Contamination from a Ground-Level Release of Fission Products, presented at the 19th DOE/NRC Nuclear Air Cleaning Conference, Seattle, Washington, August 17-21, 1986, RH0-QA-SA-25P, August 1986.

Van Keuren 1996a, J.C. Van Keuren, Tank Waste Compositions and Atmospheric Dispersion Coefficients for use in Safety Analysis Consequence Assessments, WHC-SD-WM-SARR-016 Rev 2, Ju1y 1996.

Van Keuren 1996b, J.C. Keuren, J.S. Davis, and M.L. Dentler, Toxic Chemical Considerations for Tank Farm Releases, WHC-SD-WM-SARR-011 Rev 2, July 1996. 
HNF-SD-WM-CN-096 Rev 0

\section{Attachment 1 \\ GXQ Run Files}

17 of 36 
GXQ Version 4.0A

December 19, 1994

General Purpose Atmospheric Dispersion Code

Produced by Westinghouse Hanford Company

Users Guide documented in WHC-SD-GN-SWD-30002 Rev. 1.

Validation documented in WHC-SD-GN-SWD-30003 Rev. 1.

Code Custodian is: Brit E. Hey

Westinghouse Hanford Company

P.0. Box 1970

Richland, WA 99352

(509) 376-2921

Run Date $=01 / 24 / 97$

Run Time $=14: 42: 11.42$

INPUT ECHO:

TWRS $X / Q$ - onsite \& offsite - with fallout - acute $1 \mathrm{hr}$ c. GXQ Version 4.0 Input File

c mode

1

$\mathrm{C}$

c MODE CHOICE:

$c$ mode $=1$ then $X / Q$ based on Hanford site specific meteorology

$c$ mode $=2$ then $X / Q$ based on atmospheric stability class and wind speed

$c$ mode $=3$ then $X / Q$ plot file is created

$\mathrm{C}$

c LOGICAL CHOICES:

C ifox inorm icdf ichk isite ipop

$c$ ifox $=t$ then joint frequency used to compute frequency to exceed $X / Q$

$c=f$ then joint frequency used to compute annual average $x / Q$

$c$ inorm $=t$ then joint frequency data is normalized (as in GENII)

$c \quad=f$ then joint frequency data is un-normalized

$c$ icdf $=t$ then cumulative distribution file created (CDF.OUT)

$c \quad=f$ then no cumulative distribution file created

$\mathrm{c}$ ichk $=\mathrm{t}$ then $X / Q$ parameter print option turned on

$c \quad=f$ then no parameter print

$c$ isite $=t$ then $X / Q$ based on joint frequency data for all 16 sectors

$c=f$ then $X / Q$ based on joint frequency data of individual sectors

$c$ ipop $=\mathrm{t}$ then $X / Q$ is population weighted

$c=f$ then no population weighting 
$\mathrm{C}$

c $X / Q$ AND WIND SPEED ADJUSTMENT MODELS:

$c$ ipuff idep isrc iwind
0
1

c DIFFUSION COEFFICIENT ADJUSTMENT MODELS:

c iwake ipm iflow ientr

$\begin{array}{llll}0 & 0 & 0 & 0\end{array}$

c EFFECTIVE RELEASE HEIGHT ADJUSTMENT MODELS:

C (irise igrnd) iwash igrav

$$
\begin{array}{llll}
0 & 0 & 0 & 0
\end{array}
$$

c ipuff = 1 then $X / Q$ calculated using puff mode $]$

$c \quad=0$ then $X / Q$ calculated using default continuous $p l u m e$ model

$c$ idep $=1$ then $\mathrm{plume}$ depletion model turned on (Chamberlain model)

$c$ isrc $=1$ then $X / Q$ multiplied by scalar

$c=2$ then $X / Q$ adjusted by wind speed function

$c$ iwind $=1$ then wind speed corrected for plume height

c iwake $=1$ then NRC RG 1.145 building wake model turned on

c $=2$ then MACCS virtual distance building wake model turned on

$\mathrm{c}$ ipm $=1$ then NRC RG $1.145 \mathrm{plume}$ meander model turned on

$\mathrm{c} \quad=2$ then 5 th Power Law plume meander model turned on

$=3$ then sector average model turned on

c iflow = 1 then sigmas adjusted for volume flow rate

$c$ ientr $=1$ then method of Pasquill used to account for entrainment

c irise $=1$ then MACCS buoyant plume rise model turned on

$c=2$ then ISC2 momentum/buoyancy plume rise model turned on

c igrnd $=1$ then Mills buoyant plume rise modification for ground effects

iwash $=1$ then stack downwash model turned on

igrav = 1 then gravitational settling model turned on

$=0$ unless specified otherwise, 0 turns model off

c

PARAMETER INPUT:

\section{c}

reference

c release anemometer

$c$ height

hs (m)

height

ha(m)

mixing

frequency

hs

$\overline{0.00000 E+00}$

$\overline{1.00000 \mathrm{E}+01}$

exceed

$\mathrm{hm}$ (m)

CX $(\%)$

C

c

initial initial

plume

width

plume

$W b(m)$

height

$\mathrm{Hb}(\mathrm{m})$

$\overline{1.00000 \bar{E}+03}$

$5.00000 \mathrm{E}-01$

c

\section{$\overline{0.00000 \mathrm{E}+00}$}

$\overline{0.00000 \mathrm{E}+00}$

release

duration

$\operatorname{trd}(\mathrm{hr})$

deposition

velocity

$\operatorname{vd}(\mathrm{m} / \mathrm{s})$

gravitational settling velocity $\mathrm{vg}(\mathrm{m} / \mathrm{s})$

C

c

c

c

$\mathrm{C}$

C

C

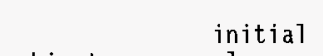

$1.00000 \mathrm{E}+00 \quad \overline{1.50000 \mathrm{E}-03}$

$1.00000 E-03$

ambient

plume

initial

temperature

temperature

plume

$\mathrm{TO}(\mathrm{C})$

flow rate

Vo $(\mathrm{m} 3 / \mathrm{s})$

$\overline{2.00000 E+01}$

$\overline{2.00000 \mathrm{E}+01}$

$\overline{1.00000 E+00}$

release

diameter

$\mathrm{d}(\mathrm{m})$

convective

heat release

rate (1)

qh (w)

(1) If zero then buoyant flux based on plume/ambient temperature difference. 


\section{HNF-SD-WM-CN-096 Rev 0}

$\mathrm{C}$

c $\quad X / Q \quad$ Wind

c scaling Speed

c factor Exponent

$c \quad c(?) \quad a(?)$

C

$\overline{1.00000 \mathrm{E}+00} \quad \overline{7.80000 \mathrm{E}-01}$

$C$

C RECEPTOR DEPENDENT DATA (no Tine 1 imit)

c FOR MODE make RECEPTOR DEPENDENT DATA

C l (site specific) sector distance receptor-height

c 2 (by class \& wind speed) class windspeed distance offset receptor-height

c 3 (create plot file) class windspeed xmax imax ymax jmax xqmin power

$\mathrm{C}$

C RECEPTOR PARAMETER DESCRIPTION

c sector $=0,1,2 \ldots($ all, $S$, SSW, etc.)

c distance $=$ receptor distance $(\mathrm{m})$

$c$ receptor height $=$ height of receptor $(\mathrm{m})$

c class $=1,2,3,4,5,6,7$ (P-G stability class $A, B, C, D, E, F, G)$

$c$ windspeed $=$ anemometer wind speed $(\mathrm{m} / \mathrm{s})$

c offset $=$ offset from plume centerline (m)

$c \operatorname{xmax}=$ maximum distance to plot or calculate to $(\mathrm{m})$

$c$ imax $=$ distance intervals

c $y \max =$ maximum off set to plot $(\mathrm{m})$

c $\operatorname{jmax}=$ offset intervals

c xamin $=$ minimum scaled $X / Q$ to calculate

$c$ power $=$ exponent in power function step size

MODE :

Site specific $X / Q$ calculated.

LOGICAL CHOICES:

Joint frequency used to calculate $X / Q$ based on frequency of exceedance.

No normalization of joint frequency.

$X / Q$ calculated for single sector.

MODELS SELECTED:

Source depletion model selected.

Default Gaussian plume model selected.

WARNING/ERROR MESSAGES:

JOINT FREQUENCY DATA:

200 AREA (HMS) - 10 M - Pasquill A - G (1983 - 1991 Average)

Created $8 / 26 / 92 \mathrm{KR}$ 
TWRS $X / Q$ - onsite \& offsite - with fallout - acute $1 \mathrm{hr}$

\begin{tabular}{|c|c|c|c|c|c|c|c|c|}
\hline SECTOR & $\begin{array}{l}\text { DISTANCE } \\
(\mathrm{m})\end{array}$ & $\begin{array}{c}\text { RECEPT } \\
\text { HEIGHT } \\
(\mathrm{m})\end{array}$ & $\begin{array}{c}\text { SECT. } \\
\text { FREQ. } \\
(\%)\end{array}$ & POPULATION & $\begin{array}{l}\text { TOTAL } \\
\text { POPULATION } \\
\text { SCALED } \\
X / Q \\
(s / \mathrm{m} 3)\end{array}$ & $\begin{array}{c}\text { AVERAGE } \\
\text { INDIVIDUAL } \\
\text { SCALED } \\
X / 0 \\
(\mathrm{~s} / \mathrm{m} 3)\end{array}$ & $\begin{array}{l}\text { ATM. } \\
\text { STAB. } \\
\text { CLASS }\end{array}$ & $\begin{array}{l}\text { WIND } \\
\text { SPEED } \\
(\mathrm{m} / \mathrm{s})\end{array}$ \\
\hline $\bar{S}$ & 100 & 0 & 6.30 & 1 & $1.43 \mathrm{E}-02$ & $1 . \overline{43 \mathrm{E}-02}$ & $\bar{E}$ & 0.89 \\
\hline SSW & 100 & 0 & 4.53 & 1 & $1.07 \mathrm{E}-02$ & $1.07 \mathrm{E}-02$ & $\mathrm{~F}$ & 2.65 \\
\hline SW & 100 & 0 & 2.93 & 1 & $1.13 \mathrm{E}-02$ & $1.13 \mathrm{E}-02$ & $\mathrm{~F}$ & 2.65 \\
\hline WSW & 100 & 0 & 2.72 & 1 & $1.14 \mathrm{E}-02$ & $1.14 \mathrm{E}-02$ & $\mathrm{~F}$ & 2.65 \\
\hline$W$ & 100 & 0 & 4.80 & 1 & $2.58 \mathrm{E}-02$ & $2.58 \mathrm{E}-02$ & G & 2.65 \\
\hline WNW & 100 & 0 & 3.98 & 1 & $1.51 E-02$ & $1.51 \mathrm{E}-02$ & G & 4.70 \\
\hline NW & 100 & 0 & 4.72 & 1 & $2.66 \mathrm{E}-02$ & $2.66 \mathrm{E}-02$ & G & 2.65 \\
\hline NNW & 100 & 0 & 4.58 & 1 & $2.66 \mathrm{E}-02$ & $2.66 \mathrm{E}-02$ & G & 2.65 \\
\hline$N$ & 100 & 0 & 4.36 & 1 & $2.77 E-02$ & $2.77 \mathrm{E}-02$ & G & 2.65 \\
\hline NNE & 100 & 0 & 2.49 & 1 & $1.38 \mathrm{E}-02$ & $1.38 \mathrm{E}-02$ & $E$ & 0.89 \\
\hline NE & 100 & 0 & 3.90 & 1 & $1.45 \mathrm{E}-02$ & $1.45 \mathrm{E}-02$ & $\mathrm{E}$ & 0.89 \\
\hline ENE & 100 & 0 & 6.17 & 1 & $2.34 \mathrm{E}-02$ & $2.34 \mathrm{E}-02$ & G & 2.65 \\
\hline $\mathrm{E}$ & 100 & 0 & 14.05 & 1 & $2.91 \mathrm{E}-02$ & $2.91 \mathrm{E}-02$ & $\bar{F}$ & 0.89 \\
\hline ESE & 100 & 0 & 18.80 & 1 & $2.83 \mathrm{E}-02$ & $2.83 \mathrm{E}-02$ & $\mathrm{~F}$ & 0.89 \\
\hline SE & 100 & 0 & 10.83 & 1 & $2.74 \mathrm{E}-02$ & $2.74 \mathrm{E}-02$ & $\mathbf{G}$ & 2.65 \\
\hline SSE & 100 & 0 & 4.78 & 1 & 1. $45 \mathrm{E}-02$ & $1.45 \mathrm{E}-02$ & G & 4.70 \\
\hline S & 15360 & 0 & 6.30 & 1 & $3.77 \mathrm{E}-06$ & $3.77 \mathrm{E}$ & $\mathrm{F}$ & 2.65 \\
\hline SSW & 15640 & 0 & 4.53 & 1 & $2.59 \mathrm{E}-06$ & $2.59 \mathrm{E}-06$ & $\mathrm{~F}$ & 4.70 \\
\hline SW & 13875 & 0 & 2.93 & 1 & $3.29 \mathrm{E}-06$ & 3.29 & $\mathrm{~F}$ & 4.70 \\
\hline WSW & 11100 & 0 & 2.72 & 1 & $4.60 \mathrm{E}-06$ & 4.60 & $\mathrm{~F}$ & 4.70 \\
\hline$W$ & 11100 & c & 4.80 & 1 & $8.29 \mathrm{E}-06$ & 8.29 & $\mathrm{~F}$ & 2.65 \\
\hline WNW & 11100 & 0 & 3.98 & 1 & $7.82 \mathrm{E}-06$ & 7.8 & G & 4.70 \\
\hline NW & 11440 & c & 4.72 & 1 & 9.95 & 9.9 & $F$ & 0.89 \\
\hline NNW & 8690 & c & 4.58 & 1 & 1.60 & 1.6 & $\mathrm{~F}$ & 0.89 \\
\hline $\mathrm{N}$ & 8760 & 0 & 4.36 & 1 & $1.61 \mathrm{E}-05$ & 1.6 & $F$ & 0.89 \\
\hline NNE & 10610 & 0 & 2.49 & 1 & 6.77 & 6.7 & $F$ & 2.65 \\
\hline NE & 10680 & 0 & 3.90 & 1 & $7.78 \mathrm{E}-06$ & 7.7 & $\mathrm{G}$ & 4.70 \\
\hline ENE & 10530 & 0 & 6.17 & 1 & $1.08 \mathrm{E}-05$ & 1.0 & $\mathrm{~F}$ & 0.89 \\
\hline$E$ & 12630 & c & 14.05 & 1 & $1.14 \mathrm{E}-05$ & 1.14 & G & 2.65 \\
\hline ESE & 18730 & c & 18.80 & 1 & $5.96 \mathrm{E}-06$ & 5.96 & G & 2.65 \\
\hline SE & 22440 & c & 10.83 & 1 & $3.89 \mathrm{E}-06$ & 3.8 & $\mathrm{~F}$ & 0.89 \\
\hline SSE & 19960 & c & 4.78 & 1 & 3.00E-06 & $3.00 \mathrm{E}-06$ & $\mathrm{~F}$ & 2.65 \\
\hline
\end{tabular}


GXQ Version 4.0A

December 19, 1994

General Purpose Atmospheric Dispersion Code

Produced by Westinghouse Hanford Company

Users Guide documented in WHC-SD-GN-SWD-30002 Rev. 1.

Validation documented in WHC-SD-GN-SWD-30003 Rev. I.

Code Custodian is: Brit E. Hey

Westinghouse Hanford Company

P.0. Box 1970

Richland, WA 99352

(509) $376-2921$

Run Date $=01 / 26 / 97$

Run Time $=14: 28: 33.19$

INPUT ECHO:

TWRS $X / Q$ - onsite \& offsite - with fallout - acute $2 \mathrm{hr}$

c GXQ Version 4.0 Input File

c mode

1

$\mathrm{C}$

c MODE CHOICE:

$C$ mode $=1$ then $X / Q$ based on Hanford site specific meteorology

$c$ mode $=2$ then $X / Q$ based on atmospheric stability class and wind speed

$c$ mode $=3$ then $X / Q$ plot file is created

c

c LOGICAL CHOICES:

C ifox inorm icdf ichk isite ipop

$c$ ifox $=t$ then joint frequency used to compute frequency to exceed $x / Q$

$c=f$ then joint frequency used to compute annual average $X / Q$

$c$ inorm $=t$ then joint frequency data is normalized (as in GENII)

$c=f$ then joint frequency data is un-normalized

$c$ icdf $=t$ then cumulative distribution file created (CDF.OUT)

$\mathrm{c}=\mathrm{f}$ then no cumulative distribution file created

$c$ ichk $=\mathrm{t}$ then $X / Q$ parameter print option turned on

$\mathrm{c}=\mathrm{f}$ then no parameter print

$c$ isite $=t$ then $X / Q$ based on joint frequency data for a 1116 sectors

$c \quad=f$ then $X / Q$ based on joint frequency data of individual sectors

$\mathrm{c}$ ipop $=\mathrm{t}$ then $X / Q$ is population weighted

$c=f$ then no population weighting 
c

c X/Q AND WIND SPEED ADJUSTMENT MODELS:

C ipuff idep isrc iwind $\begin{array}{llll}0 & 1 & 0 & 0\end{array}$

c DIFFUSION COEFFICIENT ADJUSTMENT MODELS:

c iwake ipm iflow ientr

0 l 1 0 0

c EFFECTIVE RELEASE HEIGHT ADJUSTMENT MODELS:

C (irise igrnd) iwash igrav

$\begin{array}{llll}0 & 0 & 0 & 0\end{array}$

$c$ ipuff $=1$ then $X / Q$ calculated using puff model

$c=0$ then $X / Q$ calculated using default continuous plume model

$c$ idep $=1$ then plume depletion model turned on (Chamberlain model)

$c$ isrc $=1$ then $X / Q$ multiplied by scalar

$c=2$ then $X / Q$ adjusted by wind speed function

$c$ iwind $=1$ then wind speed corrected for plume height

c iwake $=1$ then NRC RG 1.145 building wake model turned on

$c=2$ then MACCS virtual distance building wake model turned on

$c$ ipm $=1$ then NRC RG 1.145 plume meander model turned on

$\mathrm{c} \quad=2$ then 5 th Power Law plume meander model turned on

c $\quad=3$ then sector average model turned on

c iflow $=1$ then sigmas adjusted for volume flow rate

c ientr $=1$ then method of Pasquill used to account for entrainment

c irise $=1$ then MACCS buoyant plume rise model turned on

$c . \quad=2$ then ISC2 momentum/buoyancy plume rise model turned on

$c$ igrnd $=1$ then Mills buoyant plume rise modification for ground effects

$c$ iwash $=1$ then stack downwash model turned on

c igrav = 1 then gravitational settling model turned on

$c \quad=0$ unless specified otherwise, 0 turns model off

C

PARAMETER INPUT:

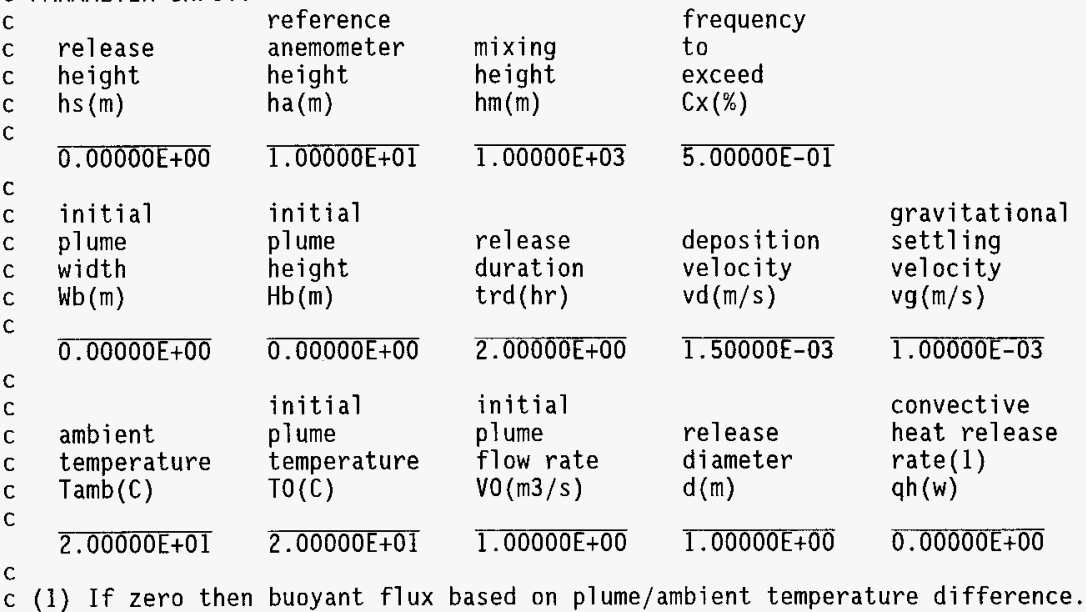




\section{HNF-SD-WM-CN-096 Rev 0}

C

c $\quad X / Q \quad$ Wind

C scaling Speed

c factor Exponent

c $c(?) \quad a(?)$

$\mathrm{C}$

\section{$\overline{1.00000 E+00} \quad \overline{7.80000 E-01}$}

$C$

C RECEPTOR DEPENDENT DATA (no 1 ine 1 imit)

C FOR MODE make RECEPTOR DEPENDENT DATA

c 1 (site specific) sector distance receptor-height

c 2 (by class \& wind speed) class windspeed distance offset receptor-height

c 3 (create plot file) class windspeed xmax imax ymax jmax xqmin power

$\mathrm{C}$

c RECEPTOR PARAMETER DESCRIPTION

c sector $=0,1,2 \ldots($ al1 $, S, S S W$, etc.)

c distance $=$ receptor distance $(\mathrm{m})$

$c$ receptor height $=$ height of receptor $(\mathrm{m})$

C class $=1,2,3,4,5,6,7$ (P-G stability class A, B, C, D, E, F, G)

$c$ windspeed $=$ anemometer wind speed $(\mathrm{m} / \mathrm{s})$

c offset $=$ offset from plume centerline $(\mathrm{m})$

c $x \max =$ maximum distance to plot or calculate to $(\mathrm{m})$

c $i \max =$ distance intervals

c $y \max =$ maximum offset to plot $(\mathrm{m})$

c jmax $=$ offset intervals

$c$ xqmin $=$ minimum scaled $X / Q$ to calculate

$c$ power $=$ exponent in power function step size

MODE :

Site specific $X / Q$ calculated.

LOGICAL CHOICES:

Joint frequency used to calculate $X / Q$ based on frequency of exceedance.

No normalization of joint frequency.

$X / Q$ calculated for single sector.

MODELS SELECTED:

NRC RG 1.145 plume meander model selected.

Source depletion model selected.

Default Gaussian plume model selected.

WARNING/ERROR MESSAGES:

JOINT FREQUENCY DATA:

200 AREA (HMS) - 10 M - Pasquil1 A - G (1983 - 1991 Average)

Created $8 / 26 / 92 \mathrm{KR}$ 
TWRS $X / Q$ - onsite \& offsite - with fallout - acute $2 \mathrm{hr}$

\begin{tabular}{|c|c|c|c|c|c|c|c|c|}
\hline SECTOR & $\begin{array}{l}\text { DISTANCE } \\
(\mathrm{m})\end{array}$ & $\begin{array}{c}\text { RECEPT } \\
\text { HEIGHT } \\
(\mathrm{m})\end{array}$ & $\begin{array}{c}\text { SECT. } \\
\text { FREQ. } \\
(\%)\end{array}$ & POPULATION & $\begin{array}{c}\text { TOTAL } \\
\text { POPULATION } \\
\text { SCALED } \\
X / Q \\
(\mathrm{~s} / \mathrm{m} 3)\end{array}$ & $\begin{array}{c}\text { AVERAGE } \\
\text { INDIVIDUAL } \\
\text { SCALED } \\
X / Q \\
(s / \mathrm{m} 3)\end{array}$ & $\begin{array}{l}\text { ATM. } \\
\text { STAB. } \\
\text { CLASS }\end{array}$ & $\begin{array}{l}\text { WIND } \\
\text { SPEED } \\
(\mathrm{m} / \mathrm{s})\end{array}$ \\
\hline $\bar{S}$ & 100 & 0 & 6.30 & 1 & $4.58 \mathrm{E}-03$ & $4.58 E-03$ & $\bar{F}$ & 4.70 \\
\hline SSW & 100 & 0 & 4.53 & l & $4.25 \mathrm{E}-03$ & $4.25 E-03$ & $\mathrm{~F}$ & 7.15 \\
\hline SW & 100 & 0 & 2.93 & 1 & $4.03 E-03$ & $4.03 E-03$ & $\mathrm{~F}$ & 2.65 \\
\hline WSW & 100 & 0 & 2.72 & 1 & $4.05 E-03$ & $4.05 E-03$ & $\mathrm{~F}$ & 2.65 \\
\hline W & 100 & 0 & 4.80 & 1 & $6.28 \mathrm{E}-03$ & $6.28 \mathrm{E}-03$ & G & 2.65 \\
\hline WNW & 100 & 0 & 3.98 & 1 & $4.63 \mathrm{E}-03$ & $4.63 \mathrm{E}-03$ & $\bar{F}$ & 4.70 \\
\hline $\mathrm{NW}$ & 100 & 0 & 4.72 & 1 & $7.01 E-03$ & $7.01 \mathrm{E}-03$ & $G$ & 2.65 \\
\hline NNW & 100 & 0 & 4.58 & 1 & $7.13 \mathrm{E}-03$ & $7.13 \mathrm{E}-03$ & $\mathrm{G}$ & 2.65 \\
\hline 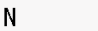 & 100 & 0 & 4.36 & 1 & $7.21 \mathrm{E}-03$ & $7.21 E-03$ & $\mathrm{~F}$ & 0.89 \\
\hline NNE & 100 & 0 & 2.49 & 1 & $4.56 \mathrm{E}-03$ & $4.56 \mathrm{E}-03$ & $E$ & 0.89 \\
\hline NE & 100 & 0 & 3.90 & 1 & $4.62 \mathrm{E}-03$ & $4.62 \mathrm{E}-03$ & $\vec{F}$ & 4.70 \\
\hline ENE & 100 & 0 & 6.17 & 1 & $7.05 \mathrm{E}-03$ & $7.05 \mathrm{E}-03$ & $G$ & 2.65 \\
\hline $\mathrm{E}$ & 100 & 0 & 14.05 & 1 & $1.04 \mathrm{E}-02$ & $1.04 \mathrm{E}-02$ & $G$ & 4.70 \\
\hline ESE & 100 & 0 & 18.80 & 1 & $1.05 \mathrm{E}-02$ & $1.05 \mathrm{E}-02$ & $\vec{G}$ & 4.70 \\
\hline$S E$ & 100 & 0 & 10.83 & 1 & 7. $23 \mathrm{E}-03$ & $7.23 \mathrm{E}-03$ & $\mathrm{~F}$ & 0.89 \\
\hline SSE & 100 & 0 & 4.78 & 1 & 4. $61 \mathrm{E}-03$ & $4.61 \mathrm{E}-03$ & $\mathrm{~F}$ & 4.70 \\
\hline c & 15360 & 0 & 6.30 & 1 & $3.34 \mathrm{E}-06$ & $3.34 \mathrm{E}-06$ & $F$ & 2.65 \\
\hline SSW & 15640 & 0 & 4.53 & 1 & $2.46 \mathrm{E}-06$ & $2.46 \mathrm{E}-06$ & $F$ & 4.70 \\
\hline SW & 13875 & 0 & 2.93 & 1 & $3.04 \mathrm{E}-06$ & $3.04 \mathrm{E}-06$ & $F$ & 4.70 \\
\hline WSW & 11100 & 0 & 2.72 & 1 & $4.15 \mathrm{E}-06$ & $4.15 E-06$ & $F$ & 4.70 \\
\hline 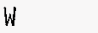 & 11100 & 0 & 4.80 & 1 & $6.72 \mathrm{E}-06$ & $6.72 \mathrm{E}-06$ & $F$ & 2.65 \\
\hline WNW & 11100 & 0 & 3.98 & 1 & $7.28 \mathrm{E}-06$ & $7.28 \mathrm{E}-06$ & G & 4.70 \\
\hline $\mathrm{NW}$ & 11440 & 0 & 4.72 & 1 & $8.12 E-06$ & $8.12 \mathrm{E}-06$ & $F$ & 0.89 \\
\hline NNW & 8690 & 0 & 4.58 & 1 & 1. $18 \mathrm{E}-05$ & $1.18 \mathrm{E}$ & $F$ & 0.89 \\
\hline $\mathrm{N}$ & 8760 & 0 & 4.36 & 1 & $1.20 \mathrm{E}-05$ & $1.20 E-05$ & $\mathrm{~F}$ & 0.89 \\
\hline NNE & 10610 & 0 & 2.49 & 1 & $5.89 \mathrm{E}-06$ & $5.89 \mathrm{E}-06$ & $\mathrm{~F}$ & 2.65 \\
\hline NE & 10680 & 0 & 3.90 & 1 & $7.11 \mathrm{E}-06$ & 7.11 & $G$ & 4.70 \\
\hline ENE & 10530 & 0 & 5.17 & 1 & $9.04 \mathrm{E}-06$ & 9.04 & $\mathrm{~F}$ & 0.89 \\
\hline$E$ & 12630 & 0 & 14.05 & 1 & $8.91 \mathrm{E}-06$ & $8.91 \mathrm{E}-06$ & $G$ & 2.65 \\
\hline ESE & 18730 & 0 & 18.80 & 1 & $5.10 \mathrm{E}-06$ & 5.10 & $G$ & 2.65 \\
\hline SE & 22440 & 0 & 10.83 & 1 & $3.24 \mathrm{E}-06$ & 3.24 & $G$ & 4.70 \\
\hline SSE & 19960 & 0 & 4.78 & 1 & $2.61 \mathrm{E}-06$ & 2.61 & $F$ & 2.6 \\
\hline
\end{tabular}


GXQ Version 4.0A

December 19, 1994

General Purpose Atmospheric Dispersion Code

Produced by Westinghouse Hanford Company

Users Guide documented in WHC-SD-GN-SWD-30002 Rev. 1.

Validation documented in WHC-SD-GN-SWD-30003 Rev. 1.

Code Custodian is: Brit E. Hey

West inghouse Hanford Company

P.0. Box 1970

Richland, WA 99352

(509) 376-2921

Run Date $=01 / 24 / 97$

Run Time $=14: 55: 43.49$

INPUT ECHO:

TWRS $X / Q$ - onsite \& offsite - with fallout - chronic 1 yr

c GXQ Version 4.0 Input File

c mode

1

$C$

c MODE CHOICE:

$C$ mode $=1$ then $X / Q$ based on Hanford site specific meteorology

$C$ mode $=2$ then $X / Q$ based on atmospheric stability class and wind speed

$c$ mode $=3$ then $X / Q$ plot file is created

C

c LOGICAL CHOICES:

C ifox inorm icdf ichk isite ipop

$c$ ifox $=t$ then joint frequency used to compute frequency to exceed $X / Q$

$c=f$ then joint frequency used to compute annual average $X / Q$

$c$ inorm $=t$ then joint frequency data is normalized (as in GENII)

$c=f$ then joint frequency data is un-normalized

$c$ icdf $=t$ then cumulative distribution file created (CDF.OUT)

$c=f$ then no cumulative distribution file created

$\mathrm{c}$ ichk $=\mathrm{t}$ then $\mathrm{X} / \mathrm{Q}$ parameter print option turned on

$c=f$ then no parameter print

$c$ isite $=t$ then $X / Q$ based on joint frequency data for all 16 sectors

$c=f$ then $X / Q$ based on joint frequency data of individual sectors

$c$ ipop $=t$ then $X / Q$ is population weighted

$c=f$ then no population weighting 
C

c X/Q AND WIND SPEED ADJUSTMENT MODELS:

C ipuff idep isre iwind

$\begin{array}{llll}0 & 1 & 0 & 0\end{array}$

c DIFFUSION COEFFICIENT ADJUSTMENT MODELS:

C iwake ipm iflow ientr
03
0
0

c EFFECTIVE RELEASE HEIGHT ADJUSTMENT MODELS:

c (irise igrnd) iwash igrav

$$
\begin{array}{llll}
0 & 0 & 0 & 0
\end{array}
$$

c ipuff $=1$ then $X / Q$ calculated using puff mode 1

$c \quad=0$ then $X / Q$ calculated using default continuous plume model

$c$ idep $=1$ then piume depletion model turned on (Chamberlain model)

$c$ isrc $=1$ then $X / Q$ multiplied by scalar

$c \quad=2$ then $X / Q$ adjusted by wind speed function

$c$ iwind $=1$ then wind speed corrected for plume height

c iwake $=1$ then NRC RG 1.145 building wake model turned on

c $\quad=2$ then MACCS virtual distance building wake model turned on

$c \mathrm{ipm}=1$ then NRC RG 1.145 plume meander model turned on

$\mathrm{c} \quad=2$ then 5 th Power Law plume meander model turned on

$=3$ then sector average model turned on

iflow = 1 then sigmas adjusted for volume flow rate

ientr $=1$ then method of Pasquill used to account for entrainment

irise $=1$ then MACCS buoyant plume rise model turned on

c $\quad=2$ then ISC2 momentum/buoyancy plume rise model turned on

igrnd $=1$ then Mills buoyant plume rise modification for ground effects

iwash $=1$ then stack downwash model turned on

igrav $=1$ then gravitational settling model turned on

c $\quad 0$ unless specified otherwise, 0 turns model off

c

PARAMETER INPUT:

release anemometer

height

height

hs (m)

ha (m)

\section{$\overline{0.00000 E+00}$}

$1.00000 \mathrm{E}+01$

mixing

frequency

\section{initial}

plume

width

$W b(m)$

initial

plume

height

$\mathrm{Hb}(\mathrm{m})$

height

$\mathrm{hm}(\mathrm{m})$

$\overline{0.00000 \mathrm{E}+00}$

$0.00000 \mathrm{E}+00$

$\overline{1.00000 E+03}$

Cx $(\%)$

\subsection{ETO}

release
duration
trd(hr)

\subsection{E-01}

c

c

C

C

C

c

ambient

$$
\text { initial }
$$

temperature

plume

$1.00000 E+00$

temperature

initial

plume

TO(C)

flow rate

$\mathrm{V} 0(\mathrm{~m} 3 / \mathrm{s})$

$\overline{2.00000 E+01}$

$\overline{2.00000 \mathrm{E}+01}$

$1.00000 E+00$

deposition

velocity

$\mathrm{vd}(\mathrm{m} / \mathrm{s})$

gravitational settling velocity $\mathrm{vg}(\mathrm{m} / \mathrm{s})$

$\overline{1.50000 E-03}$

$1.00000 \mathrm{E}-03$

C

c (1) If zero then buoyant flux based on plume/ambient temperature difference.

$$
27 \text { of } 36
$$


c

c $X / Q \quad$ Wind

C scaling Speed

c factor Exponent

$c \quad c(?) \quad a(?)$

$\mathrm{C}$

$\overline{1.00000 \mathrm{E}+00} \quad \overline{7.80000 \mathrm{E}-01}$

$\mathrm{C}$

C RECEPTOR DEPENDENT DATA (no line 1 imit)

C FOR MODE make RECEPTOR DEPENDENT DATA

C 1 (site specific) sector distance receptor-height

c 2 (by class \& wind speed) class windspeed distance offset receptor-height

c 3 (create plot file) class windspeed xmax imax ymax jmax xqmin power

$\mathrm{C}$

c RECEPTOR PARAMETER DESCRIPTION

c sector $=0,1,2 \ldots($ al1, S, SSW, etc. $)$

c distance $=$ receptor distance $(\mathrm{m})$

$c$ receptor height $=$ height of receptor $(m)$

C class $=1,2,3,4,5,6,7$ (P-G stability class A, B, C, D, E, F, G)

$c$ windspeed $=$ anemometer wind speed $(\mathrm{m} / \mathrm{s})$

$c$ offset $=$ offset from plume centerline $(\mathrm{m})$

$c x \max =$ maximum distance to plot or calculate to $(\mathrm{m})$

c $\operatorname{imax}=$ distance intervals

c $\operatorname{ymax}=$ maximum offset to plot (m)

c jmax $=$ offset intervals

$c$ xqmin = minimum scaled $X / Q$ to calculate

$c$ power $=$ exponent in power function step size

MODE :

Site specific $X / Q$ calculated.

LOGICAL CHOICES:

Joint frequency used to calculate annual average $X / Q$.

No normalization of joint frequency.

$X / Q$ calculated for single sector.

MODELS SELECTED:

Sector average model selected.

Source depletion model selected.

Default Gaussian plume model selected.

WARNING/ERROR MESSAGES:

JOINT FREQUENCY DATA:

200 AREA (HMS) - 10 M - Pasquill A - G (1983 - 1991 Average)

Created $8 / 26 / 92 \mathrm{KR}$ 
TWRS $X / Q$ - onsite \& offsite - with fallout - chronic $1 \mathrm{yr}$

\begin{tabular}{|c|c|c|c|c|c|c|c|c|}
\hline SECTOR & $\begin{array}{l}\text { DISTANCE } \\
(\mathrm{m})\end{array}$ & $\begin{array}{c}\text { RECEPT } \\
\text { HEIGHT } \\
(\mathrm{m})\end{array}$ & $\begin{array}{c}\text { SECT. } \\
\text { FREQ. } \\
(\%)\end{array}$ & POPULATION & $\begin{array}{c}\text { TOTAL } \\
\text { POPULATION } \\
\text { SCALED } \\
X / Q \\
(\mathrm{~s} / \mathrm{m} 3)\end{array}$ & $\begin{array}{l}\text { AVERAGE } \\
\text { INDIVIDUAL } \\
\text { SCALED } \\
X / Q \\
(\mathrm{~s} / \mathrm{m} 3)\end{array}$ & $\begin{array}{l}\text { ATM. } \\
\text { STAB. } \\
\text { CLASS }\end{array}$ & $\begin{array}{l}\text { WIND } \\
\text { SPEED } \\
(\mathrm{m} / \mathrm{s})\end{array}$ \\
\hline $\bar{S}$ & 100 & 0 & 6.30 & 1 & $1.52 \mathrm{E}-04$ & $1.52 E-04$ & & \\
\hline SSW & 100 & 0 & 4.53 & 1 & $9.44 \mathrm{E}-05$ & $9.44 \mathrm{E}-05$ & & \\
\hline SW & 100 & 0 & 2.93 & 1 & $8.86 \mathrm{E}-05$ & $8.86 E-05$ & & \\
\hline WSW & 100 & 0 & 2.72 & 1 & $8.88 \mathrm{E}-05$ & $8.88 \mathrm{E}-05$ & & \\
\hline$W$ & 100 & 0 & 4.80 & 1 & $1.54 \mathrm{E}-04$ & $1.54 \mathrm{E}-04$ & & \\
\hline WNW & 100 & 0 & 3.98 & 1 & 1. $24 \mathrm{E}-04$ & $1.24 \mathrm{E}-04$ & & \\
\hline NW & 100 & 0 & 4.72 & 1 & $1.41 \mathrm{E}-04$ & $1.41 \mathrm{E}-04$ & & \\
\hline NNW & 100 & 0 & 4.58 & 1 & $1.38 \mathrm{E}-04$ & $1.38 \mathrm{E}-04$ & & \\
\hline$N$ & 100 & 0 & 4.36 & 1 & $1.43 \mathrm{E}-04$ & $1.43 \mathrm{E}-04$ & & \\
\hline NNE & 100 & 0 & 2.49 & 1 & $7.99 \mathrm{E}-05$ & $7.99 \mathrm{E}-05$ & & \\
\hline NE & 100 & 0 & 3.90 & 1 & $9.59 \mathrm{E}-05$ & $9.59 \mathrm{E}-05$ & & \\
\hline ENE & 100 & 0 & 6.17 & 1 & $1.29 \mathrm{E}-04$ & $1.29 \mathrm{E}-04$ & & \\
\hline$E$ & 100 & 0 & 14.05 & 1 & $3.47 \mathrm{E}-04$ & $3.47 \mathrm{E}-04$ & & \\
\hline ESE & 100 & 0 & 18.80 & 1 & $3.75 \mathrm{E}-04$ & $3.75 \mathrm{E}-04$ & & \\
\hline SE & 100 & 0 & 10.83 & 1 & $2.31 \mathrm{E}-04$ & $2.31 \mathrm{E}-04$ & & \\
\hline SSE & 100 & 0 & 4.78 & 1 & 1. $32 \mathrm{E}-04$ & $1.32 \mathrm{E}-04$ & & \\
\hline S & 15360 & 0 & 6.30 & 1 & $2.13 \mathrm{E}-08$ & $2.13 \mathrm{E}-08$ & & \\
\hline SSW & 15640 & 0 & 4.53 & 1 & $1.30 \mathrm{E}-08$ & 1. $30 \mathrm{E}-08$ & & \\
\hline SW & 13875 & 0 & 2.93 & 1 & $1.41 \mathrm{E}-08$ & $1.41 \mathrm{E}-08$ & & \\
\hline WSW & 11100 & 0 & 2.72 & 1 & 1. $99 \mathrm{E}-08$ & $1.99 \mathrm{E}-08$ & & \\
\hline$W$ & 11100 & 0 & 4.80 & 1 & $3.58 \mathrm{E}-08$ & $3.58 \mathrm{E}-08$ & & \\
\hline WNW & 11100 & 0 & 3.98 & 1 & $2.95 \mathrm{E}-08$ & 2.95E-08 & & \\
\hline NW & 11440 & 0 & 4.72 & 1 & $3.37 \mathrm{E}-08$ & $3.37 \mathrm{E}-08$ & & \\
\hline NNW & 8690 & 0 & 4.58 & 1 & $5.34 \mathrm{E}-08$ & $5.34 \mathrm{E}-08$ & & \\
\hline$N$ & 8760 & 0 & 4.36 & 1 & $5.36 \mathrm{E}-08$ & $5.36 \mathrm{E}-08$ & & \\
\hline NNE & 10610 & 0 & 2.49 & 1 & $2.16 \varepsilon-08$ & $2.16 \mathrm{E}-08$ & & \\
\hline NE & 10680 & 0 & 3.90 & 1 & $2.64 \mathrm{E}-08$ & $2.64 \mathrm{E}-08$ & & \\
\hline ENE & 10530 & 0 & 6.17 & 1 & $3.83 \mathrm{E}-08$ & $3.83 \mathrm{E}-08$ & & \\
\hline $\bar{E}$ & 12630 & 0 & 14.05 & 1 & $8.35 \mathrm{E}-08$ & $8.35 \mathrm{E}-08$ & & \\
\hline ESE & 18730 & 0 & 18.80 & 1 & $5.15 \mathrm{E}-08$ & $5.15 \mathrm{E}-08$ & & \\
\hline SE & 22440 & 0 & 10.83 & 1 & $2.09 E-08$ & $2.09 \mathrm{E}-08$ & & \\
\hline SSE & 19960 & 0 & 4.78 & 1 & $1.27 \mathrm{E}-08$ & $1.27 \mathrm{E}-08$ & & \\
\hline
\end{tabular}


HNF-SD-WM-CN-096 Rev 0

Attachment 2 SPRAY Code Run Files

30 of 36 
SPRAY Version 3.0

May 3, 1994

Spray Leak Code

Produced by Radiological \& Toxicological Analysis

Westinghouse Hanford Company

Run Date $=01 / 23 / 97 /$

Run Time $=19: 51: 47.17$

INPUT ECHO:

C standard pit spray - optimum sector $=2$ inches

c SPRAY Version 3 Input Deck

c mode iflow iopt

$200 \quad T$

C

c MODEL OPTIONS:

$c$ mode $=1$ then orifice leak with friction assumed

c 2 then slit leak with friction assumed

c iflow $=0$ Reynold's number determines friction relation (i.e. laminar or turb.

c $=1$ friction based on laminar relation

$c=2$ friction based on turbulent relation

$c$ iopt $=T$ then optimal diameter search performed

$c=F$ then no optimal search

C

c PARAMETER INPUT:

$\mathrm{C}$

c Initial slit

c Width or slit

c Orifice Dia. Length

(in)

(in)

Slit or

$c$

C

$\overline{1.00000 E-03} \quad \overline{2.00000 E+00} \quad \overline{1.60000 E-01}$

C

C

$\mathrm{C}$

C

C

c

C

C

C

\section{Pressure}

Differential (psi)

$2.5000 \bar{E}+02$
Absolute

Surface

Roughness

(in)

0.00006 tube

0.0018 stee 1

0.0102 iron

$\overline{1.80000 \mathrm{E}-03}$
Orifice

Depth

(in)

$\overline{1.60000 \mathrm{E}-01}$

Contraction Coefficient

Velocity

Coefficient

0.61 and 0.98 for sharp edge orifice

1.00 and

1.00 and

0.98 for rounded orifice

0.82 for square edge orifice

$8.20000 E-01$ 
HNF-SD-WM-CN-096 Rev 0

C

c Specific

c Gravity

C

$1.40000 \mathrm{E}+00$

\begin{tabular}{lll}
$\begin{array}{l}\text { Dynamic } \\
\text { Viscosity } \\
\text { (centi-poise) }\end{array}$ & $\begin{array}{l}\text { Respirable } \\
\text { Diameter } \\
(\mu \mathrm{m})\end{array}$ & $\begin{array}{l}\text { RR Fitting } \\
\text { Constant } \\
(\mathrm{q})\end{array}$ \\
\cline { 1 - 1 }$\overline{1.00000 \mathrm{E}+00}$ & $\overline{1.45000 \mathrm{E}+01}$ & $2.40000 \mathrm{E}+00$
\end{tabular}

MESSAGES:

Slit Mode 1

Code search for optimal equivalent diameter.

OUTPUT:

Liquid Velocity $=7.91 \mathrm{E}+01 \mathrm{ft} / \mathrm{s} \quad 2.41 \mathrm{E}+01 \mathrm{~m} / \mathrm{s}$

Reynolds Number $=7.78 \mathrm{E}+03$ Turbulent Flow

Sauter Mean Diameter $=5.28 \mathrm{E}+01 \mu \mathrm{m}$

Optimum Slit Width $=4.55 \mathrm{E}-03$ in

Respirable Fraction $=1.61 \mathrm{E}-02$

Total Leak Rate $=2.24 \mathrm{E}+00 \mathrm{gpm} \quad 1.41 \mathrm{E}-04 \mathrm{~m} 3 / \mathrm{s} \quad 1.98 \mathrm{E}+02 \mathrm{~g} / \mathrm{s}$

Respirable Leak Rate $=3.61 \mathrm{E}-02 \mathrm{gpm} \quad 2.28 \mathrm{E}-06 \mathrm{m3} / \mathrm{s} \quad 3.19 \mathrm{E}+00 \mathrm{~g} / \mathrm{s}$ 
SPRAY Version 3.0

May 3, 1994

\begin{abstract}
Spray Leak Code
Produced by Radiological \& Toxicological Analysis

Westinghouse Hanford Company
\end{abstract}

Run Date $=01 / 27 / 97 /$

Run Time $=08: 46: 35.94$

INPUT ECHO:

c $10 \%$ solids pit spray - optimum sector $=2$ inches

c SPRAY Version 3 Input Deck

c mode iflow iopt

$200 \quad T$

$\mathrm{C}$

c MODEL OPTIONS:

$c$ mode $=1$ then orifice leak with friction assumed

c $\quad 2$ then slit leak with friction assumed

c iflow $=0$ Reynold's number determines friction relation (i.e. laminar or turb.

c $=1$ friction based on laminar relation

c $\quad=2$ friction based on turbulent relation

$c$ iopt $=T$ then optimal diameter search performed

$c=F$ then no optimal search

$\mathrm{C}$

C PARAMETER INPUT:

c Initial S1it

c Width or slit

c Orifice Dia.

c (in)

Length

Slit or

C
$\overline{1.00000 E-03}$

\section{$\overline{2.00000 \mathrm{E}+00}$}
$\overline{1.60000 E-01}$

(in)

Depth

(in)

c

C

c

Absolute

Surface

Roughness

Contraction

Velocity

(in)

Coefficient

Coefficient

Pressure
Differential

0.00006 tube 0.61

and

0.98 for sharp edge orifice

0.0018 steel 1.00 and

0.98 for rounded orifice

(psi)

0.0102 iron 1.00 and

0.82 for square edge orifice

C

\title{
$\overline{2.50000 \mathrm{E}+02}$
}

$\overline{1.80000 E-03}$

$1.00000 E+00$

$8.20000 \mathrm{E}-01$ 
HNF-SD-WM-CN-096 Rev 0

C

c Fluid Dynamic Respirable RR Fitting

c Specific Viscosity Diameter Constant

c Gravity (centi-poise) ( $\mu \mathrm{m}) \quad$ (q)

c $\overline{1.20000 \mathrm{E}+00} \overline{1.00000 \mathrm{E}+00} \quad \overline{2.15000 \mathrm{E}+0 \mathrm{I}} \overline{2.40000 \mathrm{E}+00}$

\section{MESSAGES :}

Sl it Model

Code search for optimal equivalent diameter.

$$
\text { OUTPUT: }
$$

Liquid Velocity $=8.62 \mathrm{E}+01 \mathrm{ft} / \mathrm{s} \quad 2.63 \mathrm{E}+01 \mathrm{~m} / \mathrm{s}$

Reynolds Number $=7.39 \mathrm{E}+03$ Turbulent Flow

Sauter Mean Diameter $=5.10 \mathrm{E}+01 \mu \mathrm{m}$

Optimum S1 it Width $=4.63 \mathrm{E}-03$ in

Respirable Fraction $=4.44 \mathrm{E}-02$

Total Leak Rate $=2.49 \mathrm{E}+00 \mathrm{gpm}$

Respirable Leak Rate $=1.10 \mathrm{E}-01 \mathrm{gpm}$

$1.18 \mathrm{E}-04 \mathrm{~m}$

$1.57 \mathrm{E}-04 \mathrm{~m} 3 / \mathrm{s}$

$6.96 \mathrm{E}-06 \mathrm{~m} 3 / \mathrm{s}$

$1.88 \mathrm{E}+02 \mathrm{~g} / \mathrm{s}$

$8.35 \mathrm{E}+00 \mathrm{~g} / \mathrm{s}$ 


\section{CHECKLIST FOR PEER REVIEW}

Document Reviewed: REFINED RADIOLOGICAL AND TOXICOLOGICAL CONSEQUENCES OF BOUNDING SPRAY LEAK ACCIDENTS IN TANK FARM WASTE TRANSFER PITS, D.A. Himes, 2/12/97

Scope of Review: entire document

$\frac{\text { Yes No } N A}{\ltimes][][]}$ *

$\bowtie$ [ ] [ ] Problem completely defined.

$[x][][]$

$[x][][]$

$x][$ [ ] ]

(x) [ ] [ ]

$\mathbb{E}][\mathrm{j}]$

[ ] [ ] $]$

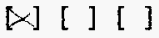

[ $[$ ] ] ]

$\underset{\infty}{\infty}[][]$

[ [ ] [ ]

[ ] [ ] [ [ ] [ ]

$\bowtie][$ ] ]

[ ] [ ] ऐ]

[ ] $\mathbb{\infty}$ *

$W[$ [ [ ] Document approved. review, with no gaps. applicable. of results. document reviewed. against references. limits. statement. standards

Previous reviews complete and cover analysis, up to scope of this

Accident scenarios developed in a clear and logical manner.

Necessary assumptions explicitly stated and supported.

Computer codes and data files documented.

Data used in calculations explicitly stated in document.

Data checked for consistency with original source information as

Mathematical derivations checked including dimensional consistency

Models appropriate and used within range of validity or use outside range of established validity justified.

Hand calculations checked for errors. Spreadsheet results should be treated exactly the same as hand calculations.

Software input correct and consistent with document reviewed.

Software output consistent with input and with results reported in

Limits/criteria/guidelines applied to analysis results are appropriate and referenced. Limits/criteria/guidelines checked

Safety margins consistent with good engineering practices.

Conclusions consistent with analytical results and applicable

Results and conclusions address all points required in the problem

Format consistent with appropriate NRC Regulatory Guide or other

Review calculations, comments, and/or notes are attached.

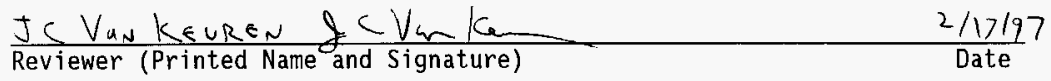

* Any calculations, comments, or notes generated as part of this review should be signed, dated and attached to this checklist. Such material should be labeled and recorded in such a manner as to be intelligible to a technically qualified third party. 


\section{HNF-SD-WM-CN-096 Rev 0 \\ HEDOP REVIEW CHECKLIST \\ for \\ Radiological and Nonradiological Release Calculations}

Document reviewed (include title or description of calculation, document number, author, and date, as applicable):

\section{REFINED RADIOLOGICAL AND TOXICOLOGICAL CONSEQUENCES OF BOUNDING SPRAY LEAK ACCIDENTS IN TANK FARM WASTE TRANSFER PITS, D.A. Himes, 2/12/97}

Submitted by:

D.A. Himes

Date Submitted:

Scope of Review: entire document

YES NO* N/A

[X] [ ] [ ] 1. A detailed technical review and approval of the environmental transport and dose calculation portion of the analysis has been performed and documented.

X] [ ] [ ] 2. Detailed technical review(s) and approval(s) of scenario and release determinations have been performed and documented.

$\bowtie$ [ [ ] [ ] 3. HEDOP-approved code(s) were used.

×] [ ] [ ] 4. Receptor locations were selected according to HEDOP recommendations.

メ] [ ] [ ] 5. A11 applicable environmental pathways and code options were included and are appropriate for the calculations.

$\times$ [ ] [ ] 6. Hanford site data were used.

X] [ ] [ ] 7. Model adjustments external to the computer program were just ified and performed correctly.

$\bowtie$ [ ] [ ] 8. The analysis is consistent with HEDOP recommendations.

9. Supporting notes, calculations, comments, comment resolutions, or other information is attached. (Use the "Page 1 of X" page numbering format and sign and date each added page.)

$\infty$ [ ]

10. Approval is granted on behalf of the Hanford Environmental Dose Overview Panel.

* A1l "NO" responses must be explained and use of nonstandard methods justified.

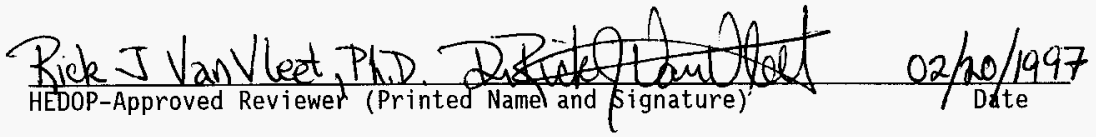

COMMENTS (add additional signed and dated pages if necessary): 
DISTRIBUTION SHEET

\begin{tabular}{|c|c|c|c|c|c|}
\hline To & \multirow{2}{*}{\multicolumn{3}{|c|}{$\begin{array}{l}\text { From } \\
\text { Fluor Daniel Northwest } \\
\text { Specialty Eng ineering }\end{array}$}} & \multicolumn{2}{|l|}{ Page 1 of 1} \\
\hline $\begin{array}{l}\text { TWRS SAR Engineering } \\
\text { DE\&S Hanford, Inc. }\end{array}$ & & & & \multicolumn{2}{|l|}{ Date $2 / 12 / 96$} \\
\hline \multicolumn{4}{|l|}{ Project Title/Work Order } & \multicolumn{2}{|c|}{ EDT No. 615793} \\
\hline \multicolumn{4}{|c|}{$\begin{array}{l}\text { Refined Radiological and Toxicological Consequences of Bounding } \\
\text { Spray Leak Accidents in Tank Farm Waste Transfer Pits }\end{array}$} & \multicolumn{2}{|c|}{ ECN No. N/A } \\
\hline Name & MSIN & $\begin{array}{l}\text { Text } \\
\text { With All } \\
\text { Attach. }\end{array}$ & Text Only & $\begin{array}{l}\text { Attach./ } \\
\text { Appendix } \\
\text { Only }\end{array}$ & $\begin{array}{l}\text { EDT/ECN } \\
\text { Only }\end{array}$ \\
\hline $\begin{array}{l}\text { G.W. Ryan (4) } \\
\text { B.E. Hey } \\
\text { D.A. Himes (2) } \\
\text { J.C Van Keuren } \\
\text { R.J. Van Vleet } \\
\text { Central Files (original + 1) } \\
\text { Docket Files (2) } \\
\text { TWRS S\&L Files (2) }\end{array}$ & $\begin{array}{l}A 3-37 \\
A 3-34 \\
A 3-34 \\
A 3-34 \\
A 3-34 \\
A 3-88 \\
B 1-17 \\
A 2-26\end{array}$ & $\begin{array}{l}X \\
X \\
X \\
X \\
X \\
X \\
X \\
X\end{array}$ & & & \\
\hline
\end{tabular}

